\title{
Virulence Mechanisms of Leukotoxin from Aggregatibacter actinomycetemcomitans
}

\author{
Anders Johansson ${ }^{1}$ and Sotos Kalfas ${ }^{2}$ \\ ${ }^{1}$ Umeå University, \\ ${ }^{2}$ Aristotle University of Thessaloniki \\ ${ }^{1}$ Sweden \\ ${ }^{2}$ Greece
}

\section{Introduction}

Aggregatibacter actinomycetemcomitans is a gram-negative bacterium that is present in the oral cavity of a large proportion of the human population (Zambon et al., 1983; Henderson et al., 2010) The bacterium is acquired through transmission from infected individuals and thought to initially colonize oral mucosa as a facultative intracellular pathogen (Fine et al., 2006). When the bacteria translocate to a site in the subgingival crevices, a persistent colonization may lead to periodontal destruction and development of periodontitis in susceptible individuals (Fig. 1) (Philstrom et al., 2005; Darveau 2010). The prevalence of this bacterium shows a great variation depending on geographic origin, age and life stile of the examined population (Kinane et al., 2008; Habek 2010). A. actinomycetemcomitans is a part of the normal flora in many healthy individuals but it is also a major agent in some aggressive forms of periodontitis (Fine et al., 2006). Periodontitis is a chronic infection characterized by the destruction of tooth-supporting structures (Darveau 2010). The number and composition of bacteria in the subgingival dental plaque, as well as life stile and genetic predisposition are factors that determine the outcome of the disease activity (Philstrom et al., 2005; Darveau 2010). The genetic diversity among different isolates of A. actinomycetemcomitans is great and its ability to express and release virulence factors varies (Henderson et al., 2010). The different adhesins and fimbriae expressed by this bacterium have been shown to be important factors that promote colonization at the various ecological niches of the human oral cavity (Fine et al., 2006).

A. actinomyctemcomitans expresses two exotoxins, a cytolethal distending toxin (Cdt) and a leukotoxin. Cdt's are expressed by a number of gram-negative bacteria and causes death of the host cells by blocking their proliferation (Belibasakis et al., 2004). The leukotoxin selectively affects human cells of hematopoetic origin by binding to the lymphocyte function associated receptor 1 (LFA-1) and cause disruption of the membrane integrity (Lally et al., 1999). Leukotoxin belongs to the Repeat in Toxin family (RTX) and shares genomic organization and molecular structures with RTX proteins produced by a number of other gram-negative bacteria (Linhortavá et al., 2010). The expression of leukotoxin and Cdt varies among different $A$. actinomycetemcomitans isolates and high leukotoxin expression has been shown to correlate with disease while the role of Cdt still is more unclear (Henderson et al., 
2010). The genetic features and the molecular structure of leukotoxin have recently been described in detail (Kachlany 2010; Johansson 2011). This chapter focuses on the functional aspects of the leukotoxin as a virulence factor associated with pathogenic cellular mechanisms.

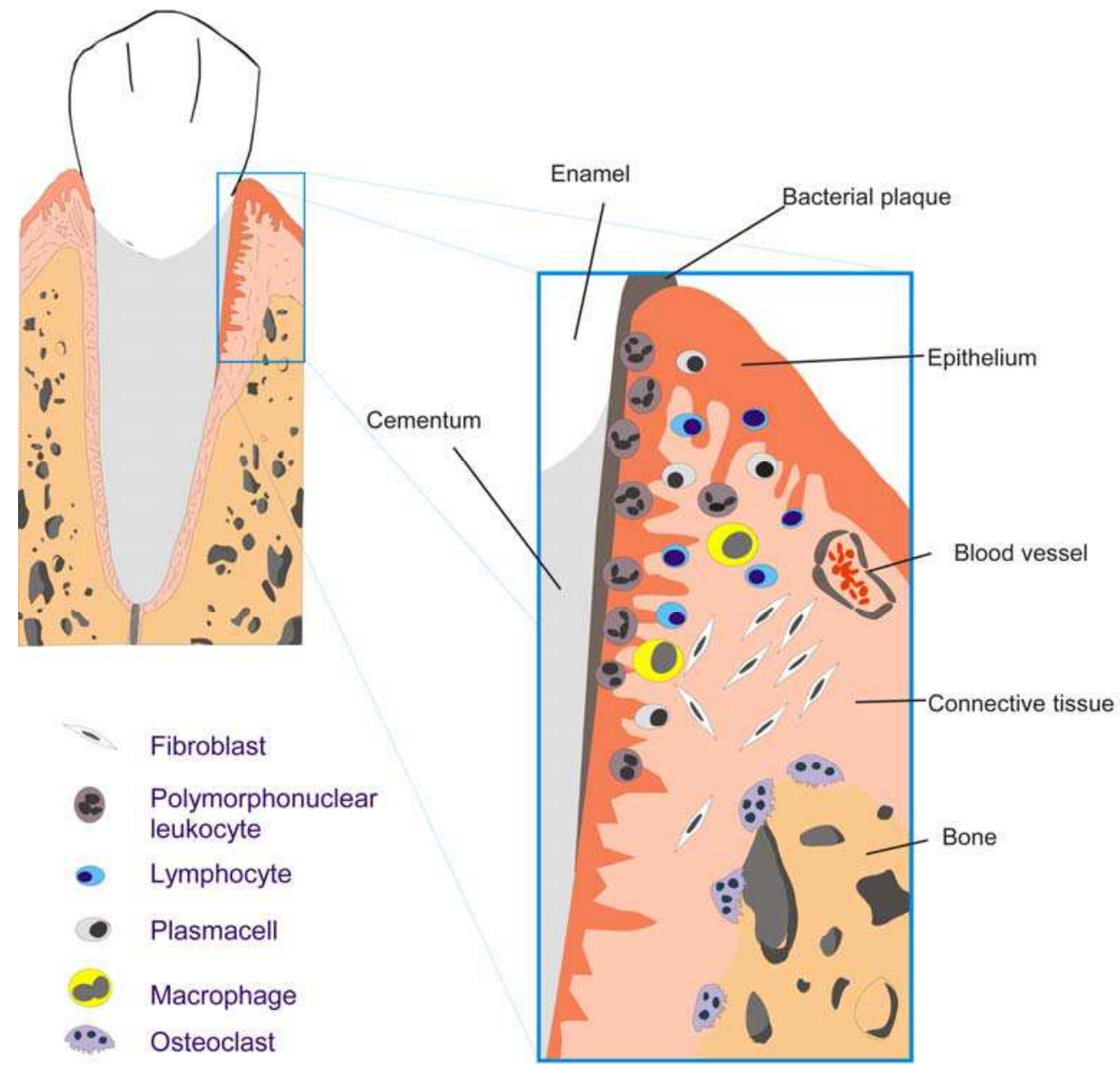

Fig. 1. Schematic illustration of cells and tissues involved in the pathogenesis of periodontal diseases. Microbes adhere to the epithelium and tooth surface and form a biofilm (microbial plaque). Persistent presence of this biofilm activates an inflammatory response in the surrounding tissues, which recruits a substantial number of immune cells from the peripheral circulation to the inflamed site. An imbalance in the host response might lead to degradation of the tooth supporting tissues, bone and connective tissue, and finally to tooth loss. A large number of microbial components, such as toxins and proteases that are released from the biofilm can affect the cellular response of the host. 


\section{Aggregatibacter actinomycetemcomitans and its association to disease}

As mentioned, periodontitis is a chronic inflammatory condition in the periodontal tissues, which leads to periodontal attachment loss and destruction of the alveolar bone that houses the teeth. Based on clinical characteristics, several forms of periodontitis are recognized. Most prevalent is the slowly progressing chronic periodontitis while the so called aggressive form shows a more rapid tissue loss and often occurs in young subjects (Pihlstrom et al., 2005).
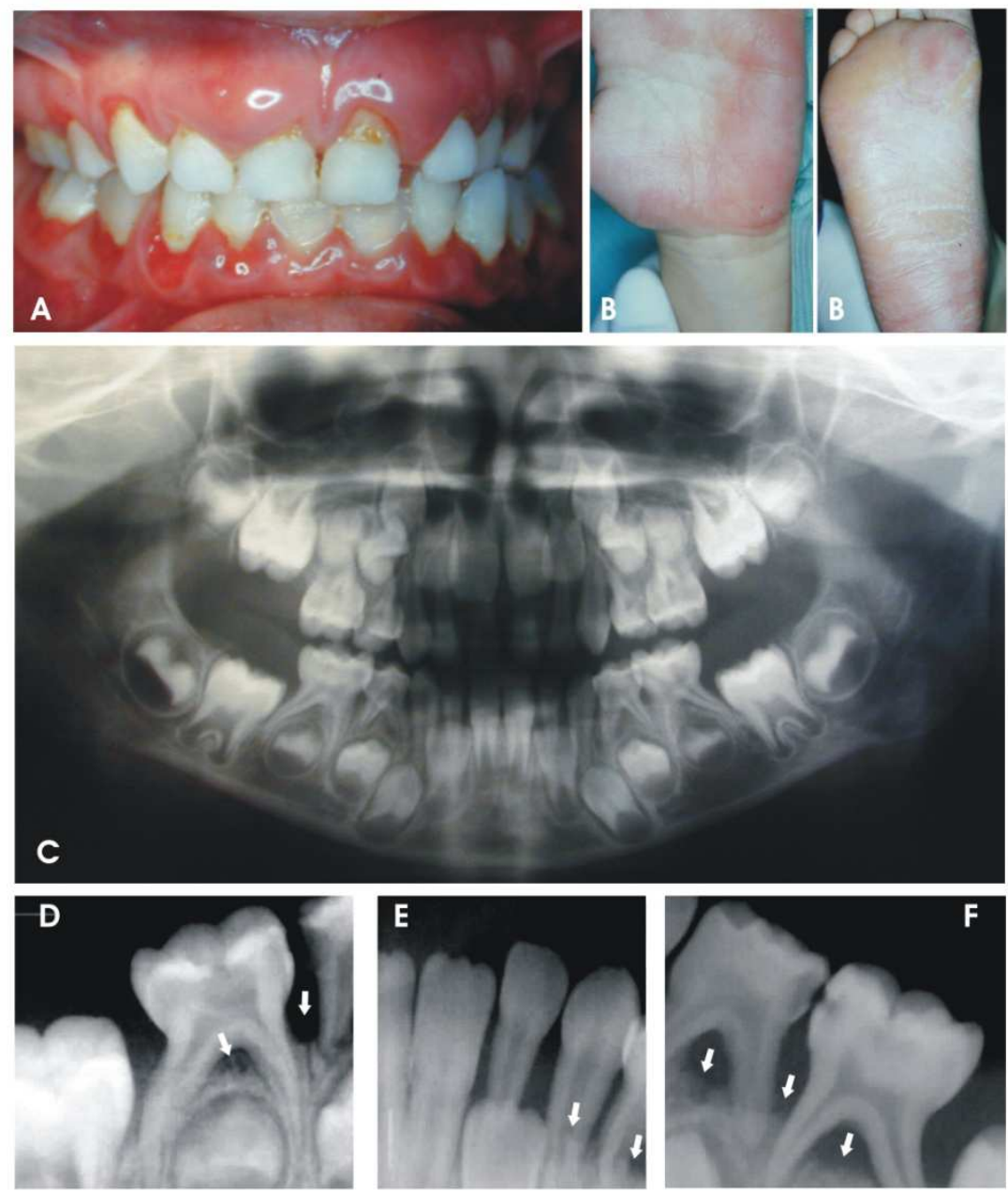

Fig. 2. Papillon-Lefèvre syndrome in a 6-year old child. A. Clinical manifestation of the extended periodontal inflammation affecting the primary dentition. B. Hyperkeratotic palmo-plantar skin lesions C-F. Radiographs showing the severe bone loss (arrows) around the teeth. Cultures of samples from the periodontal pockets revealed the rich presence (up to $70 \%$ of the total sample flora) of A. actinomycetemcomitans. (unpublished data of author SK). 
Periodontitis can also be developed in conjuction with systemic diseases or medication and its severity depends on the underlying condition, the most severe forms being found in patients with disorders in the cellular defense, mostly in neutrophils, e.g. Papillo-Lefèvre syndrome, Kostmann syndrome, various neutropenias, and Chediak-Higashi syndrome (Fig. 2) (Reichart \& Dornow 1978; Deasy et al. 1980; Deas et al. 2003; Tempel et al. 1972; Saglam et al. 1995; Defraia \& Marinelli 2001; De Vree et al. 2000).

The etiology of periodontitis is microbial. The infection is caused in most cases by consortia of bacteria with a predominance of gram-negative anaerobic rods that colonize the periodontal pocket (Pihlstrom et al., 2005; Darveau 2010). Approximately 700 different bacterial species can be detected in samples from the subgingival plaque biofilm (Socransky $\&$ Haffajee 2005). The majority of these species can be isolated from samples of both healthy and periodontally diseased subjects. In plaque samples from diseased sites, the number and proportion of pathogenic organisms are elevated (Berezew \& Darveau 2011; Nishihara \& Koseki 2004).

In some forms of aggressive periodontitis A. actinomycetemcomitans is often found in high numbers in subgingival plaque samples from the affected tooth sites (Fine et al., 2007). Especially in patients with certain neutrophil disorders, A. actinomycetemcomitans is the main pathogen colonizing the periodontal area (Stabholz et al. 1995; Kleinfelder et al. 1996; Velazco et al. 1999; Pütsep et al., 2002). These epidemiological data indicate that establishment of $A$. actinomycetemcomitans in the periodontium as the main pathogen and development of inflammation depends on the lack of functional neutrophils in this area.

Besides the pathogens in the oral biofilm, genetic and environmental host factors contribute to periodontitis development (Nishihara \& Koseki 2004). Furthermore, an association between periodontal infections and other inflammatory systemic diseases, such as cardiovascular diseases and diabetes, is well established, but the underlying specific mechanism is still unknown (Pihlstrom et al., 2005).

The prevalence of $A$. actinomycetemcomitans in subgingival plaque samples can be estimated by traditional culture methods, as well as by molecular (PCR-based) techniques (Fine et al., 2007). In an examined population, the proportion of A. actinomycetemcomitans positive individuals varies with periodontal status, age, ethnicity and geographic origin (Fine et al., 2007). Genetic differences of both patients and potential pathogens are of importance for a better insight into the etiology of periodontal diseases (Rylev \& Kilian 2008). Longitudinal studies have shown that periodontally healthy children that harbour A. actinomyctemcomitans have an increased risk to develop Localized aggressive periodontitis (LAP) (Van der Velden et al., 2006; Fine et al., 2007). A specific clone (JP2) is strongly associated with LAP in subjects of African origin, and differs from other clones of this species by several genetic peculiarities, including a 530-bp deletion in the promotor region of the leukotoxin gene operon, which results in an enhanced expression of leukotoxin (Brogan et al. 1994; Haubek et al., 2007 \& 2008). Healthy adolescents harbouring this clone were shown to have an 18-fold increased risk to develop periodontal attachment loss within a 2-year follow up period compared to the A. actinomycetemcomitans negative controls (Haubek et al., 2008). In contrast to the promoter deletion in the JP2, in a Japanese strain was shown that an insertion mutation increases the expression of the leukotoxin operon (He et al., 1999). However, no reports are yet available that associates the presence of this specific highly toxic clone with the onset and progression of aggressive periodontitis in this population. 


\section{Genetic characteristics of Aggregatibacter actinomycetemcomitans}

A. actinomycetemcomitans is a member of the bacterial family Pasteurellaceae (Kilian et al., 2006). Recently, it was reclassified in the new genus Aggregatibacter together with its close relatives Aggregatibacter (Haemophilus) aphrophilus and Aggregatibacter (Haemophilus) segnis (Nørskov-Lauritsen \& Kilian 2006). Molecular genetics has demonstrated a degree of biodiversity in the oral microflora and A. actinomycetemcomitans is genetically heterogeneous and comprises distinct clonal lineages that may have different virulence potentials (Kittichotirat et al., 2011). Seven serotypes have been identified among $A$. actinomycetemcomitans isolates; each serotype represents a distinct clonal lineage (Kaplan et al., 2002; Kilian et al., 2006; Takada et. al., 2010). The complete genome sequence of $A$. actinomycetemcomitans serotype $\mathrm{b}$ strain HK1651 from the JP2 clone has been available since 2002 (http://www.genome.ou.edu/act.html). Genome sequencing of 14 different strains from $A$. actinomycetemcomitans species have identified a pangenome consisting of 3301 genes, including 2034 core genes and 1267 flexible genes (Kittichotirat et al., 2011). The natural competence of this bacterium for horizontal gene transfer might explain the substantial genetic diversity shown within this species (Wang et al., 2002). The within-species variable virulence may be attributed to a strain-to-strain variation in genome content and regulation of virulence gene expression (Kittichotirat et al., 2011). Future work with genomic characterization of A. actinomycetemcomitans might contribute to identify specific virulent clones other than the already well characterized highly leukotoxic JP2 clonal types (Haubek 2010; Kittichotirat et al., 2011). In addition, population genetic analyses of this bacterium have been giving information about global dissemination of this species and its strict horizontal transfer pattern together with the presence of several genetic peculiarities give also information about population trades (Kilian et al., 2006; Habek et al., 2007).

\section{Expression and secretion of A. actinomycetemcomitans leukotoxin}

The leukotoxin operon consists of four coding genes designated $l t x \mathrm{C}, l+x \mathrm{~A}, l+x \mathrm{~B}$ and $l t x \mathrm{D}$ and an upstream promoter gene (Lally et al., 1989; Kraig et al., 1990). ltxA is encoding for the structure of the toxin, $l t x \mathrm{C}$ for components required for posttranslational acylation of the toxin and $l+x B$ and $D$ for transport of the toxin to the bacterial outer membrane. The leukotoxin operon is organized as illustrated in fig. 3 , this pattern being similar to the gene organization found for other proteins of the RTX-family (Welch et al., 2001; Linhartová et al., 2010).

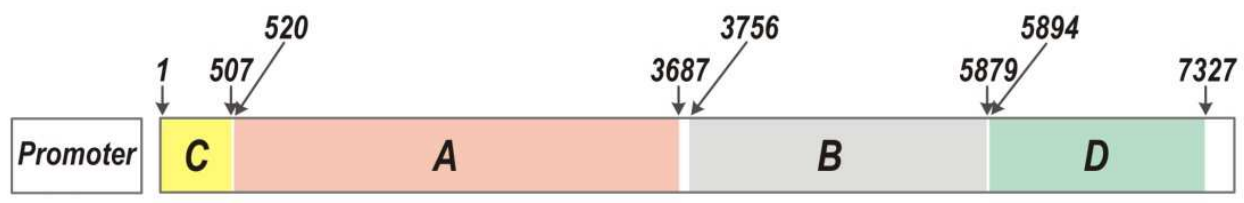

Fig. 3. Schematic illustration of the operon organization of A. actinomycetemcomitans leukotoxin.

There is a great variation in leukotoxin expression in vitro (Fig. 4), although all $A$. actinomycetemcomitans strains harbor a complete leukotoxin operon (Henderson et al., 2010). 
Zambon and co-workers (1983) showed that A. actionomycetemcomitans isolated from periodontally diseased subjects exhibited significantly enhanced leukotoxicity compared with isolates from periodontally healthy subjects. Interestingly, certain clones of the bacterium with enhanced leukotoxin expression have been shown to have a modified promoter in the leukotoxin operon (Brogan et al., 1994; He et al., 1999). The cellular and molecular mechanisms in which a modified leukotoxin promoter enhances the expression of leukotoxin are not known. The most well known phenomenon is the highly leukotoxic JP2 clonal strains of $A$. actinomycetemcomitans characterized by a 530-bp deletion in the promoter of the leukotoxin operon (Haubek 2010). Hypertonic $\mathrm{NaCl}$ extracts of bacteria from this clone analyzed by SDS-PAGE and Comassie staining reveald a protein pattern that was dominated by a $116 \mathrm{kDa}$ band shown to be the leukotoxin (Johansson et al., 2000a) (Fig. 6). Presence of the JP2 clone is highly associated to aggressive forms of periodontitis and shown to correlate with disease onset of adolescents in Morocco (Haubek et al., 2008). This highly leukotoxic clone (JP2) has recently been reported to also colonize subjects with, by genotyping confirmed, North-European origin (Claesson et al., 2011). Clonal diversity analysis of JP2-like isolates have shown that all strains of this clone have a common ancestor from Northern Africa (Haubek et al., 2007). The high accumulation of this clone in subjects of African origin has indicated a possible host tropism, but could also be a result of the strict vertical transmission pattern of this bacterium (Kilian et al., 2006; Haubek 2010).

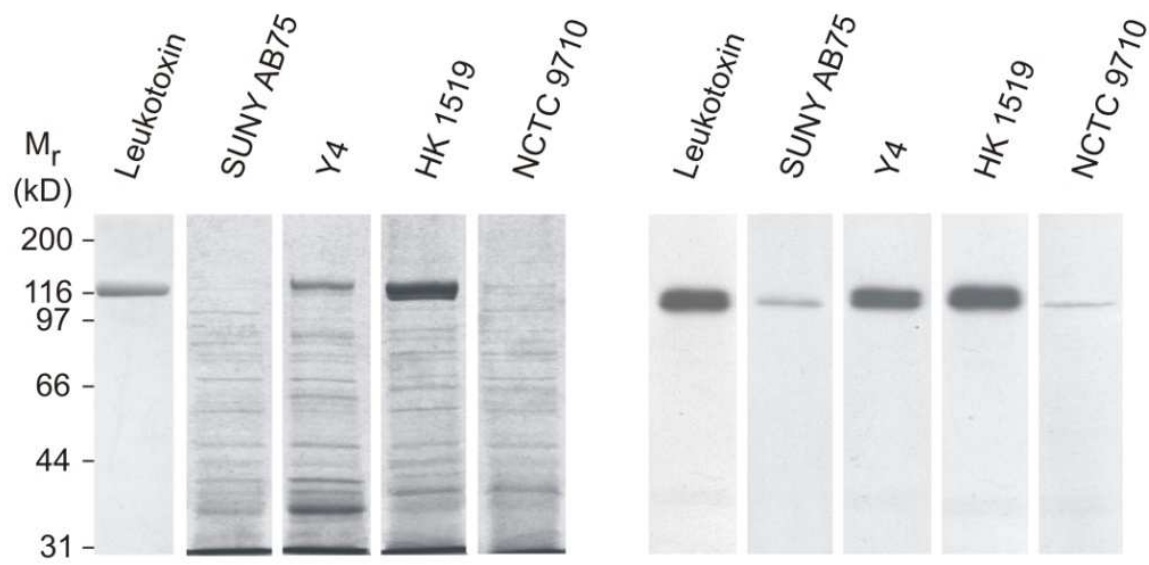

Fig. 4. The left figure shows $\mathrm{NaCl}$ extracts from different strains of A. actinomycetemcomitans separated on $8 \%$ SDS-PAGE and stained with Comassie blue. The left lane contain the purified leukotoxin and the other 4 lanes contain extract from 3 strains representing 3 different serotypes (SUNY AB75 serotype a, Y4 serotype b and NCTC 9710 serotype c) and having intact leukotoxin promoter and 1 strain serotype $b$ from the highly leukotoxic JP2 clonal type (strain HK1519). The right figure shows the same SDS-PAGE separated extracts blotted on a PVDF membrane and visualized by western blot technique with a leukotoxin specific rabbit antiserum.

The expression of leukotoxin is also regulated by environmental factors, such as growth conditions and substrates (Kachlany et al., 2010). The expression of leukotoxin by various strains of A. actinomycetemcomitans at the infected site of the host is still unknown. 
The expressed leukotoxin is transported to the bacterial outer membrane by a type I secretion system (Kuhnert \& Christensen 2008). Three proteins, LtxB, LtxD and TdeA, are reported to be required for export of the toxin to the bacterial outer membrane and are organized in accordance to the figure below (Fig. 5) (Crosby \& Kachlany 2007).

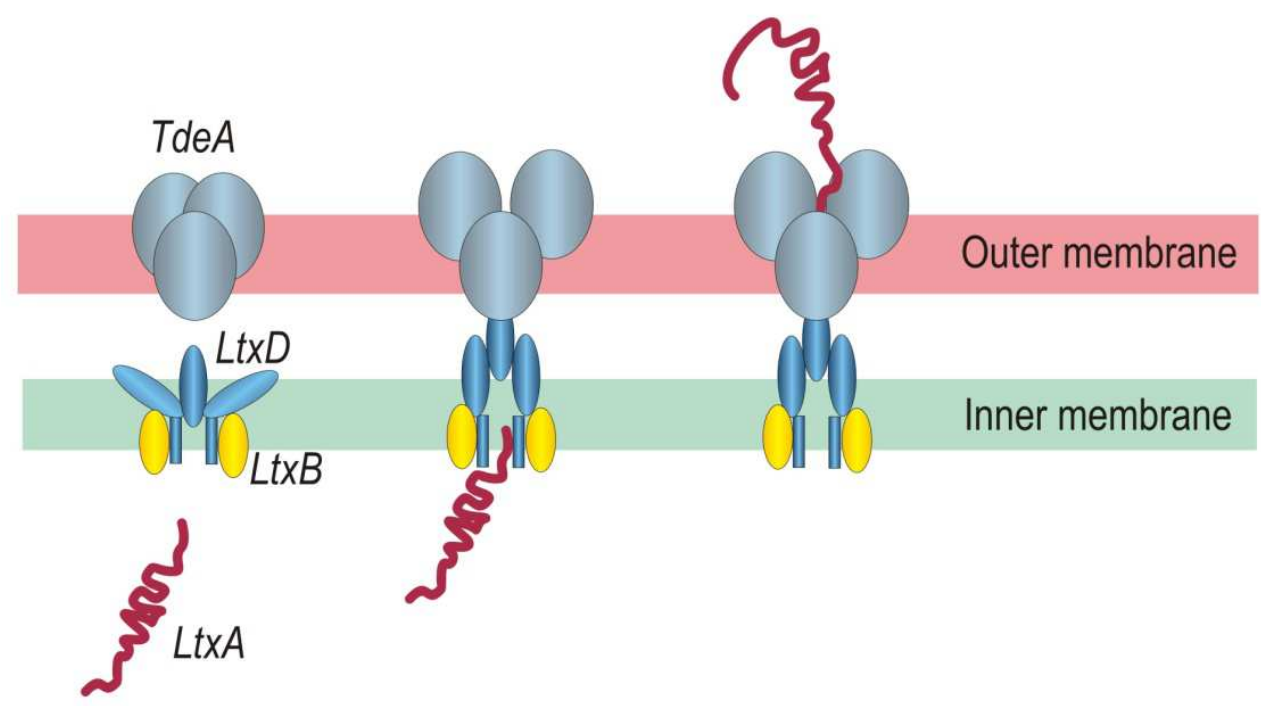

Fig. 5. Schematic illustration of the type I secretion system required for export of the expressed A. actinomycetemcomitamns leukotoxin to the bacterial outer membrane (OM). $\mathrm{IM}=$ Inner membrane and TdeA $=$ a TolC like proten.

In addition, presence of serum proteins also mediates a similar release of the toxin from the bacterial outer membrane, which indicates involvement of competitive mechanisms (Johansson et al., 2003). Different culture conditions have been shown to determine the distribution of the expressed toxin between the bacterial outer membrane and the culture supernatant (Kachlany et al., 2000; 2010). Whether leukotoxin remains associated to the bacteria in the periodontal pocket is not known. However, the serum mediated release of the toxin (Johansson et al., 2003), as well as the intense systemic immune response to the toxin (Brage et al., 2011), possibly indicate a release of the toxin from bacteria in the biofilm in vivo. Among the different proteins of the RTX family, A. actinomycetemcomitans leukotoxin differ from the other toxins by its high isoelectric point, as well as the membrane association of the expressed protein (Welch 2001; Linhortavá et al., 2010). This property of leukotoxin further supports the importance of electrostatic forces for its association to the bacterial outer membrane.

The secreted leukotoxin has been shown to be easily inactivated by environmental proteases and superoxide radicals (Johansson et al., 2000b, 2001; Balashova et al., 2007). This degradation of the toxin molecule can be inhibited by the presence of superoxide dismutase 
(SOD) produced by A. actinomycetemcomitans and the naturally occurring protease inhibitors of human serum (Johansson et al., 2001; de Haar et al., 2006; Balashova et al., 2007). In 1981, McArthur and co-workers showed that the activity of leukotoxin in interaction with polymorphonuclear leukocytes (PMNs) was enhanced by the presence of human serum (McArthur et al., 1981). This phenomenon could later be explained by the protective effect of the serum protease inhibitors on leukotoxin degradation caused by lysosomal enzymes released by the affected PMNs (Johansson et al., 2001).

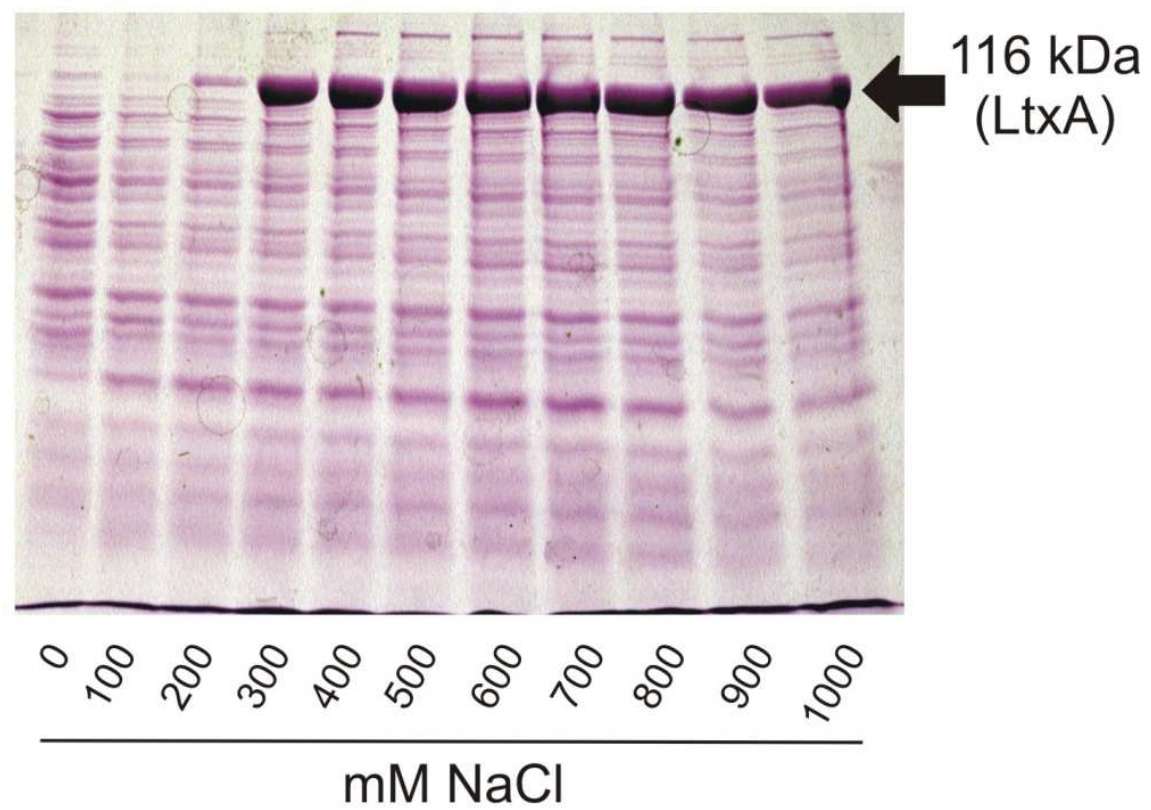

Fig. 6. Surface extract of bacteria from a highly leukotoxic (JP2) strain of $A$. actinomycetemcomitans (HK1619) separated by SDS-PAGE and stained with Comassie blue. The $116 \mathrm{kDa}$ leukotoxin is released from the bacterial surface at $\mathrm{NaCl}$ concentration $\geq 300 \mathrm{mM}$, becoming the dominant band in the protein profile of the extracts (Johansson et al., 2000a).

\section{Molecular aspects of $\boldsymbol{A}$. actinomycetemcomitans leukotoxin}

\subsection{Structure}

Leukotoxin (LtxA) expressed by A. actinomycetemcomitans is a large pore-forming protein that belongs to the RTX family of proteins. Leukotoxin consists of 1055 amino acids encoded by the leukotoxin gene in the leukotoxin operon (Lally et al., 1989; Kraig et al., 1990). The molecule can be divided into four regions based upon analysis of the amino acid sequence, the N-terminal region, the central region, the repeat region and the C-terminal region (Fig. 7) (Lally et al., 1996).

The N-terminal region at residues 1-408 exhibits alternating hydrophobic and hydrophilic clusters. The pore-forming regions of RTX proteins have been suggested to be mediated by 
the hydrophobic clusters located between residues 175-400 (Welch et al., 2001). The central region at residues 409-729 contains large hydrophilic domains and the two acylation sites of leukotoxin located at lysine ${ }_{562}$ and lysine 687 (Balashova et al., 2009). The fatty acids at these positions have been shown necessary for the activity of the toxin and suggested to contribute to the anchorage at the target cell membrane. The repeat region consists of tandem repeats of a cassette with nine amino acids located between residues 730-900 and 14 such repeats have been identified in this region of leukotoxin (Stanley et al., 1994). The target cell receptor LFA-1 binds to the repeat region and this interaction has been shown to determine the host cell specificity of leukotoxin (Stanley et al., 1994; Lally et al., 1994). In addition, the glycine rich repeats in this region have a strong capacity to bind $\mathrm{Ca}^{2+}$ and presence of these cations mediates increased binding of the toxin to leukotoxin-sensitive LFA-1 expressing cells (Lally et al., 1997). Finally, residues 901-1055 at the C-terminal end have been shown to be needed for export of the toxin to the bacterial outer membrane by interactions with secretory proteins (Stanley et al., 1991; Sato et al., 1993). This region of leukotoxin contains 20 additional basic amino acid residues, which differs the leukotoxin from the other RTX-proteins and confers its high isoelectric point (9.7) (Kraig et al., 1990). The four regions of leukotoxin described above are shared among the various toxins in the diverse family of pore forming RTX proteins but their amino acid sequence homology is limited to about $40-50 \%$, with the highest homology between their repeat regions and the lowest between their C-terminal regions (Kraig et al., 1990). A partial denaturation of the leukotoxin molecule has been reported to enhance its leukotoxicity, which indicates that conformational changes affect the activity of the toxin (Lear et al., 2000). Some minor differences have been identified on the leukotoxin genes between different $A$. actinomycetemcomitans isolates but whether these differences interfere with leukotoxicity is not known (Lally et al., 1989; Kraig et al., 1990; Chen et al., 2009, Kittichotirat et al., 2011). The crystalline structure of leukotoxin has not yet been solved, which limits the available information about the molecular structures of the protein.

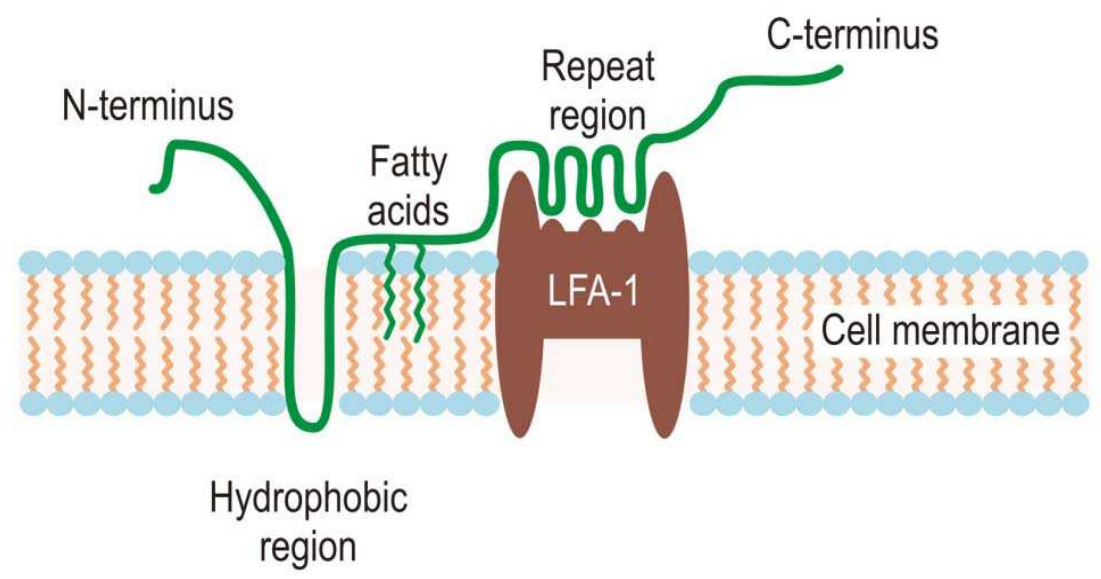

Fig. 7. Schematic illustration of the molecules involved in the interaction between $A$. actinomycetemcomitans leukotoxin and the target cell membrane. 


\subsection{Interaction with the target cell membrane}

Leukotoxin exhibits a unique specificity to cells of haematopoetic origin from humans and some other primates (Lally et al., 1994). This restricted host cell specificity indicates that the species-specific effect of leukotoxin is mediated through a unique receptor on the target cells and that a precise region in the toxin recognizes and interacts with the receptor (Dileepan et al., 2007; Kieba et al., 2007). The principal feature of this species recognition region of leukotoxin is a series of 14 tandemly repeated amino acid sequences in the repeat region of the toxin (Stanley et al., 1994).

The leukotoxin has been shown to bind to surfaces of toxin-sensitive LFA-1-expressing cells, as well as toxin-resistant cells without LFA-1 expression (Lally et al., 1997). It has been suggested that the role of LFA-1 in leukotoxin-mediated cell lysis is to help the protein to have a correct orientation on the target cell membrane (Fig. 7) (Lally et al., 1999). Further, the two fatty acids strengthen the anchorage of the toxin when inserted in the target cell membrane and the hydrophobic domain forms small pores in the membrane. It has been stated that low concentration of the toxins might induce apoptosis through loss of membrane integrity caused by the small pores and that higher concentration of the toxin allows oligomerization of leukotoxin-LFA-1 complexes on the target cell membrane mediating a rapid and complete membrane collapse (Lally et al., 1999). In addition, leukotoxin has been shown to require lipid rafts for target cytotoxicity, which also indicates the importance of a high mobility on the target cell membrane (Fong et al., 2006).

The domain of leukotoxin that recognizes the target cell receptor has been determined to residues 688-941 examined by epitope mapping with monoclonal antibodies (Stanley et al., 1994). The LFA-1 molecule identified as the leukotoxin target cell receptor is a heterodimer consisting of the $\alpha_{\mathrm{L}}(\mathrm{CD} 11 \mathrm{a})$ and $\beta_{2}$ (CD18) subunits. The residues 1-128 on human CD11a has been shown to determine the human specificity of leukotoxin-induced cell lysis (Kieba et al., 2007). In addition, the extracellular region of human CD18 (residues 500-600) has been shown critical for conferring susceptibility to leukotoxin-induced cell lysis (Dileepan et al., 2007). The most important ligand of LFA-1 is the intercellular adhesion molecule 1 (ICAM1), but this interaction does not coincide with the residues identified for leukotoxin binding (Dileepan et al., 2007; Kieba et al., 2007, Dustin et al., 2004). This finding indicates that the intracellular signaling mediated by the LFA-1 ligand binding is not activated by the leukotoxin binding. Three different affinity states (low, intermediate, high) of LFA-1 that interfere with ligand binding have been described (Shimaoka et al., 2003). If these different affinity states of the leukotoxin receptor interfere with the interactions between leukotoxin and its target cells is not known.

\section{Cellular and molecular host response against $A$. actinomycetemcomitans leukotoxin}

The ability of $A$. actinomycetemcomitans extracts to cause death of leukocytes was first shown more than 30 years ago (Baehni et al., 1979; Tsai et al., 1979). A protein named leukotoxin was indentified as the responsible molecule for this effect that was restricted to affect human PMNs and monocytes (Baehni et al., 1979; Tsai et al., 1979; Taichman et al., 1980). It has later been shown that leukotoxin also can affect human lymphocytes and erythrocytes from human and animal origin, however, at higher toxin concentrations than those lysing 
PMNs and monocytes (Mangan et al., 1991; Balashova et al., 2006). Even though leukotoxin affects all subsets of human immune cells it is highly immunogenic and induces a specific acquired systemic immune response in the infected host (Ebersole 2003; Brage et al., 2011).

\subsection{Acquired humoral immune response against leukotoxin}

The specific role of humoral immunity in periodontal disease progression has not been fully elucidated, although the production of antibody response is suggested to be beneficial to the host in fighting periodontal infections (Ebersole 2003). On the other hand, the acquired immune response against periodontal pathogens has been shown to mediate disease associated mechanisms, such as bone resorption (Taubman et al., 2005; Teng 2003). It has clearly been shown that leukotoxin specific antibodies are present in the peripheral circulation of both periodontally healthy and diseased subjects (Kachlany et al., 2000; Califano et al., 1997). Plasma samples from the subjects with specific immunoreactivity against leukotoxin have been shown to neutralize leukotoxin activity and have also enhanced antibody titers against whole cells of A. actinomycetemcomitans in comparison with samples from subjects without immunoreactivity to leukotoxin (Califano et al., 1997). It has also been shown that systemic leukotoxin neutralization is correlated to the presence of this bacterium in the subgingival plaque (Källestål et al., 1991; Sjödin et al., 1995; Carlsson et al., 2006). The prevalence of systemic leukotoxin antibodies has been shown to be present in $>50 \%$ in samples from adults and without significant differences in relation to periodontitis (Brage et al., 2011; Johansson et al., 2011). Interestingly, systemic leukotoxin neutralization correlates to decreased risk of the incidence of stroke in woman (Johansson et al., 2005). The mechanism behind this phenomenon has not yet been determined but a possible role of leukotoxin is suggested in the association seen between peridontitis and cardiovascular diseases (Pihlstrom et al., 2005).

A general opinion is that the humoral immune response against antigens of the oral subgingival microbiota is both local and systemic (Ebersole 2003). Whether the leukotoxin activity can be neutralized in the gingival pocket by specific antibodies is not known and there has been no report about the presence of leukotoxin neutralizing antibodies in the gingival crevicular fluid. The strong correlation between prevalence of higly leukotoxic $A$. actinomycetemcomitans and the development of attachment loss (Haubek et al., 2008) indicates a minor role of neutralizing antibodies in the infected periodontal pocket. However, it can be assumed that systemic leukotoxin neutralizing antibodies are an important protection against the systemic side effects, such as increased risk for diabetes and cardiovascular diseases that are associated with periodontitis. It has previously been shown that systemic antibodies against leukotoxin completely neutralize its activity even at high dilutions of the positive sera (Brage et al., 2011). In addition, the systemic leukotoxinneutralizing capacity negatively associates to stroke while the systemic immunoreactivity to A. actinomycetemcomitans also shows a negative association to rheumatoid arthritis (Johansson et al., 2005; Okada et al., 2011). The mechanism behind these negative associations has not been elucidated. It could be speculated that the ability of leukotoxin to specifically affect the immune cells, in particular the antigen presenting monocytes/macrophages, causes a delayed acquired immune response in a primary $A$. actinomycetemcomitans infection. 


\subsection{Polymorphonuclear leukocytes}

PMNs are the first defense cells to be recruited in the acute phase of an inflammation, as in a periodontal infection (Kantarci \& van Dyke 2005). These defense cells are often found at high numbers in the infected periodontal pocket, attracted from the peripheral circulation through chemotaxis towards a gradient of molecules released from the dental plaque, as well as activated host cells. Although PMNs are crucial for phagocytizing and killing bacteria, they also release substances that mediate tissue destruction in aggressive forms of periodontitis (Kantarci et al., 2003). PMNs in the periodontium have been described as a "double-edged sword", capable of producing periodontal disease as well as protecting against the disease (Lamster et al., 1992). Leukotoxin as well as leukotoxic bacteria have been shown to efficiently cause death of human PMNs and consequently the leukotoxin is assumed to protect A. actinomycetemcomitans against phagocytic killing (Henderson et al., 2010). The protection occurs in relation to the leukotoxin production of the bacterial population (Johansson et al., 2000c). In a mixture of low-leukotoxic bacteria, human serum and PMNs ( 25 bacteria/PMN), which is agitated at $37^{\circ} \mathrm{C}$ under anaerobic condition, the bacteria are efficiently phagocytized and killed (Johansson et al., 2000c). In contrast, in the presence of highly leukotoxic (JP2-clone) bacteria and under the same conditions, the PMNs failed to phagocytize and kill the bacteria. Transmission electron microscopy pictures of the exposed PMNs showed a peripheral translocation of the granules in cells exposed to the highly leukotoxic bacteria (Fig. 8). Further analysis of PMNs exposed to leukotoxin showed an extracellular release of proteolytic enzymes from both primary and secondary granules (Johansson 2000b). More over, the interaction between leukotoxin and PMNs mediates activation and release of matrix metalloproteinase 8 (Claesson et al., 2002). Taken together these findings indicate that leukotoxin before causing death of the PMNs induces activation and release of proteolytic enzymes from these cells, which can contribute to periodontal tissue destruction.

Whether leukotoxin can exist as a biologically active protein in the infected periodontal pocket has not yet been examined. The presence of serum proteins and the relatively high $\mathrm{pH}(\approx 8)$ in the pocket indicates that leukotoxin is released from the bacterial surface in this ecological niche (Kraig et al., 1990; Johansson et al., 2003). The released toxin is an easy target for inactivation by several of the components present in the periodontal pocket, such as superoxide radicals and proteinases released from the host defense cells or the colonizers of the subgingival biofilm (Johansson et al., 2000a, 2003; Balashova et al., 2007). In addition, systemic leukotoxin specific antibodies neutralize leukotoxic activity, but if these antibodies are functional in the environment of the infected periodontal pocket is not known (Brage et al., 2011). There are also molecules that can protect leukotoxin from inactivation, such as the serum proteinase inhibitors and SOD expressed by $A$. actinomycetemcomitans (Johansson et al., 2001; Balashova et al., 2007). Probably, the great variation over time in the balance between these factors and the leukotoxin produced at a site of infection affects the progression of periodontal destruction.

As mentioned above, impaired PMN function is closely associated with periodontitis and functional PMNs seem to be of certain importance for combating A. actinomycetemcomitans establishment in the subgingival biofilm (de Haar et al., 2006; Kantarci et al., 2003; Carlsson et al., 2006; Pütsep et al., 2002). For instance, PMNs of subjects with Kostmann's syndrome are immature and expresses truncated LL37, a cathelicidin with antibacterial effect against 
A. actinomycetemcomitans (Pütsep et al., 2002). Furthermore, subjects with Papillon-Lefèvre syndrome have truncated PMN serine proteases, this causing an enhanced leukotoxin sensitivity due to impaired capacity to degrade extracellular leukotoxin by the released lysosomal PMN enzymes (de Haar et al., 2006).

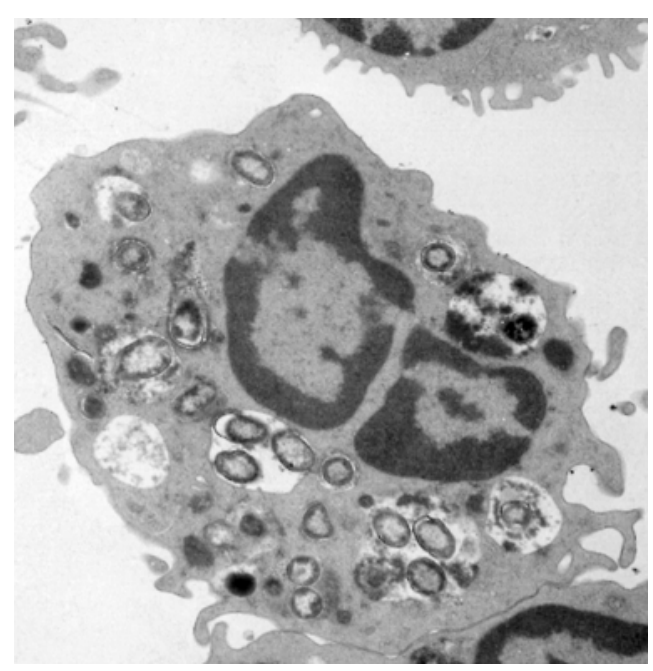

Minimally-leukotoxic

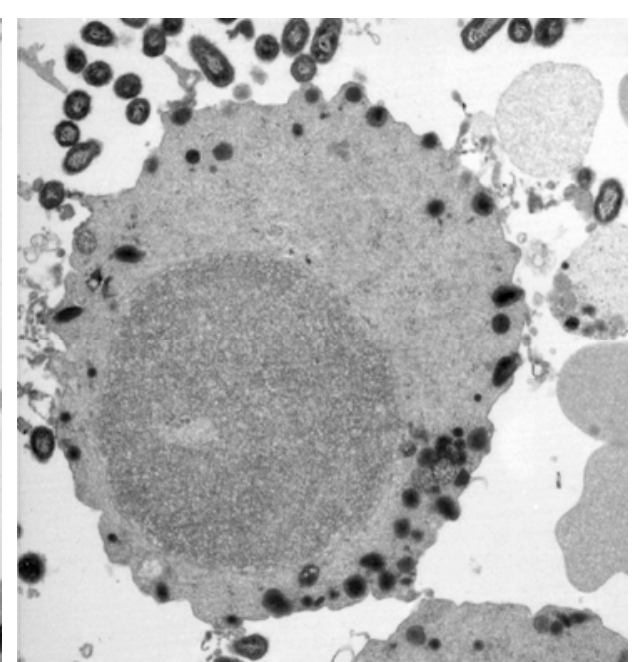

Highly-leukotoxic

Fig. 8. PMNs exposed to alive A. actinomycetemcomitans (25 bacteria/PMN) for $10 \mathrm{~min}$ in the presence of $10 \%$ human non-immune sera. The mixture was gently agitated at $37^{\circ} \mathrm{C}$ in an anaerobic atmosphere. The minimally leukotoxic bacteria are phogocytized and killed by the PMN, while the highly leukotoxic bacteria (JP2) resist PMN phagocytosis and causes extracellular release of lysosomal components (Johansson et al., 2000c).

\subsection{Lymphocytes}

The lymphocytes were initially described as leukotoxin resistant cells (Baehni et al., 1979; Tsai et al., 1979). The first observation of leukotoxin susceptible cells of lymphocytic origin was by Simpson and co-workers (Simpson et al., 1988) who showed that several lymphoid cell lines were killed in the presence of leukotoxin. In addition, leukotoxin was shown to suppress function of peripheral blood lymphocytes (Shenker et al., 1994). A few years later, Mangan and co-workers (1991) showed that T-cells isolated from human peripheral blood were affected by leukotoxin. This leukotoxin-induced T-cell death was a slow process compared to the lysis of human cells of myeloid origin, the death being caused through apoptosis (Mangan et al., 1991). Human natural killer (NK) cells are affected by leukotoxin in a similar way as the T-cells, while the effects of leukotoxin to human B-cells or plasmacells have not been studied (Shenker et al., 1994). Human lymphocytes show a great heterogeneity in regard to leukotoxin sensitivity and a subgroup of these cells are shown to be lysed at approximately the same concentrations as human PMNs (Kelk et al., 2003). The 
lymphocytes with different leukotoxin sensitivity was not further characterized in this study but analysis of CD11a expression on the cell membrane showed a heterogenic distribution pattern for this cell population. The reason for the variation in leukotoxin sensitivity between PMNs and lymphocytes is not known. The suggested oligomerization of leukotoxin-LFA-1 complex and the need of lipid rafts on the target cell membrane may indicate that the composition of membrane molecules on the target cells determines the source of leukotoxin-induced death mechanisms (Lally et al., 1999). In cells from the human myeloid carcinoma cell line HL-60, low concentrations of leukotoxin cause apoptosis while higher concentrations lead to necrosis (Korostoff et al., 1998).

Cells of lymphoid origin are rare in the infected periodontal pocket but they reside at high numbers in the surrounding tissues as well as in the lymph glands (Kinane et al., 2002). It has been known for $>30$ years that the development of periodontitis involves a switch from a $\mathrm{T}$ cell lesion to one involving large numbers of B-cells and plasma cells. A shift in the balance between Th1 and Th2 subsets of T-cells is found in periodontal inflammation, with the Th2 cells to associate with chronic periodontitis (Ohlrich et al., 2009). More recently, T regulatory (Treg) and Th17 cells have been detected in periodontal tissues indicating that these cells also are of importance in the host response and pathogenesis of periodontal disease (Garlet 2010). The strong humoral immune response induced by leukotoxin indicates direct contact between this molecule and cells of lymphoid origin (Brage et al., 2011; Califano et al., 1997). The ability of leukotoxin to induce apoptosis in lymphocytes might impair the acquired immune response of periodontal infections. The ability of leukotoxin to affect the lymphocytes also indicates a possible role of this molecule in Th1/Th2/Th17 differentiation, a process that seems to be of importance in the pathogenesis of inflammatory diseases.

\subsection{Monocytes/macrophages}

It was early shown that human monocytes were as sensitive to leukotoxin, as human PMNs (Tsai et al., 1979). Killing of monocytes by the toxin proceeds through three distinct phases 1) cessation of the membrane undulating folding and an accumulation of granulae in the perinuclear area, 2) abnormal membrane movement and strings of cytoplasm projecting from the cell, and 3) explosive release of cytoplasmic material from the cells (Taichman et al., 1980). However, it should be taken into consideration that these studies were made with a crude leukotoxin extract that contained a lot of other bacterial components. Rabie and co-workers (Rabie et al., 1988) showed that purified leukotoxin caused a rapid death of human monocytes in mixtures of the toxin with peripheral blood mononuclear leukocytes (MNL).

More recently, analyses of different subsets of leukocytes separated from peripheral blood of a single donor showed that monocytes had an enhanced sensitivity to leukotoxin compared to PMNs and lymphocytes (Kelk et al., 2003). The leukotoxin-induced monocyte lysis was shown to involve activation of caspase-1, which indicates involvement of proinflammatory intracellular signalling (Fig. 9). Caspase-1 is a cytosolic cysteine proteinase that specifically induces activation and secretion of the pro-inflammatory cytokines

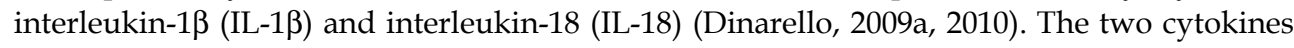
are expressed as biologically inactive precursors and have to be cleaved by caspase- 1 for activation and secretion. Caspase- 1 is activated by incorporation in a cytosolic multimer 
complex named the inflammasome (Latz 2010). The intracellular signalling pathways involved in leukotoxin-induced inflammasome activation in human monocytes/macrophages have not yet been determined. A partial characterization of this process indicates involvements of activation of the purogenic receptor P2X $X_{7}$ (Kelk et al., 2011). Caspase- 1 activation is also caused by several other gram-negative pathogens, such as Salmonella and Shigella species, and has been shown to be an important innate immune effector mechanism against intracellular bacteria (Miao et al., 2010).

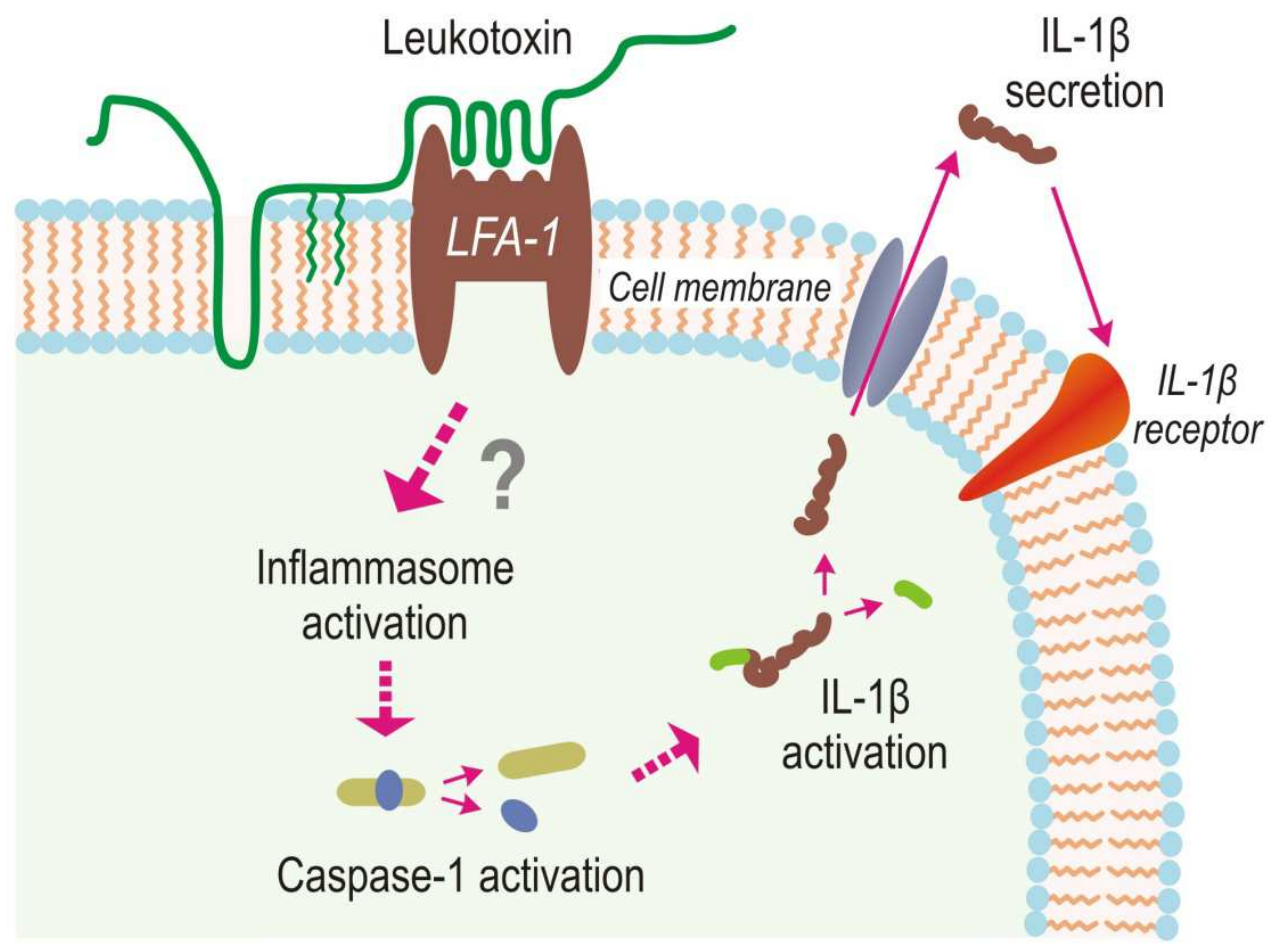

Fig. 9. Schematic illustration of the leukotoxin interaction with macrophages. Leukotoxin adheres to the cell membrane through binding to the LFA-1 dimer and it further anchors by inserting the fatty acid into the membrane lipid bilayer. The hydrophobic domain of the toxin is thought to cause small pores in the cell membrane. Through still undefined intracellular signalling pathways, this interaction with the target cell causes activation of caspase- 1 and IL-1 $\beta$ that is secreted in a bioactive form from the affected cell.

IL-1 $\beta$ is a key component involved in acute and chronic inflammation, which makes the discovery of the leukotoxin induced IL-1 $\beta$ activation relevant and important (Kelk et al., 2005; Dinarello, 2011). IL-1 is an important regulator of bone resorption, which associates this cytokine to the alveolar bone loss seen in periodontitis (Schett, 2011; Dinarello, 2011; 
Preshaw \& Taylor, 2011). Analysis of gingival exudates have shown increased IL-1 concentration associated to periodontitis (Reinhardt et al., 2010; Preshaw \& Taylor, 2011). Periodontal pockets examined from the same subject have indicated an association between high levels of A. actinomycetemcomitans and increased IL-1 $\beta$ concentration (Kelk et al., 2008).

The finding that leukotoxin induces activation of caspase- 1 in human inflammatory defence cells indicates a new role of this virulence factor as a mediator of pro-inflammatory host response. Human macrophages (adherent blood monocytes) exposed to leukotoxin activates a rapid and abundant secretion of bioactive IL-1 $\beta$ (Kelk et al., 2005). Culture supernatants of leukotoxin-exposed macrophages activate bone resorption in cultured mouse calvaria, while presence of monoclonal antibodies against IL-1 $\beta$ abolishes this activation. This data indicate that bone resorption caused by culture supernatants of leukotoxin-exposed macrophages is mainly caused by released IL-1 $\beta$. Moreover, exposure of human macrophages to components of gram-negative oral pathogens causes an increased accumulation of cytosolic pro-IL-1 $\beta$ that was not activated and released (Kelk et al., 2008). Leukotoxin or leukotoxic A. actinomycetemcomitans activates cleavage and secretion of this accumulated macrophage IL-1 $\beta$, while $A$. actinomycetemomitans mutants without leukotoxin expression fail to cause this phenomenon. IL-1 $\beta$ secretion was activated already at a ratio of 1 bacterium/macrophage when using a highly leukotoxic A. actinomycetemcomitans strain or at a 10 times higher ratio when strains with low leukotoxicity were used (Kelk et al., 2008). Taken together, these data show that leukotoxin is the major A. actinomycetemcomitans component that induces activation and release of IL-1 $\beta$ from human macrophages and that this effect is further enhanced by priming the macrophages with other bacterial components.

Macrophages are rare cells in the healthy periodontium but are often found in high numbers in tissues from periodontal lesions (Kinane \& Lappin, 2002). These cells are recruited to the infected site from the peripheral blood monocytes that are attracted by ICAM-1 expressing endothelial cells. The monocytes are passing through the vessel wall and are migrating in the connective tissue towards a gradient of chemoattractants that are released from the biofilm and the activated host cells (Geissmann et al., 2010). During diapedesis the monocytes differentiate into macrophages with a concomitant up-regulation of their inflammatory machinery, which continues during the migration. This process involves an accumulation of pro-inflammatory precursor molecules, such as IL-1 $\beta$ and IL-18, in the migrating macrophages (Dinarello, 2009b). A secondary stimulus is needed to induce activation and release of the accumulated precursors of IL-1 $\beta$ and IL-18 in the primed macrophages (Dinarello, 2010). In the case of an infection containing $A$. actinomycetemcomitans, the gradient of bioactive components in the connective tissue will contain leukotoxin, and the migrating macrophages will sooner or later meet leukotoxin concentrations that activate secretion of cytokines in the surrounding tissues. If this process is activated in the tooth supporting tissues in vicinity to the infection it might cause imbalance in the host inflammatory response and it might promote pathogenic cellular mechanisms. Some preliminary results indicate an association between enhanced IL-1 $\beta$ levels in gingival crevicular fluid and high number of A. actinomycetemcomitans in the periodontal pocket (Kelk et al., 2008). Interestingly, recent results suggest that IL-1 $\beta$ is transported into the A. actinomycetemcomitans cells and binds to the trimeric form of 
intracellular ATP synthase subunit $\beta$ (Paino et al., 2011). This specific mechanism might universally enhance biofilm resistance to host defence by binding IL-1 $\beta$ during inflammation.

The strong systemic immune response of the host to leukotoxin in A. actinomycetemcomitans infected subjects indicates direct contact between the antigent-presenting macrophages and leukotoxin (Califano et al., 1997; Brage et al., 2011). The enhanced leukotoxin-sensitivity of human macrophages indicates that these antigen presenting cells might be affected during a primary infection with leukotoxic A. actinomycetemcomitans, which might cause a delayed acquired immune response.

The pro-inflammatory response associated to degenerative diseases is at focus of research in many different medical disciplines (Dinarello, 2010). A variety of safe and effective antiinflammatory agents are available today and commonly used in treatments of many autoimmune or auto-inflammatory disorders, neurodegenerative disease, or cancer. Increased knowledge of the cellular and molecular mechanisms involved in the pathogenesis of periodontitis might open up possibilities for new specific therapeutic agents and strategies in the future. The cellular and molecular targets for specific blockage of the inflammatory response to infection, as well as the possible therapeutic agents now and in the future, have recently been extensively reviewed (Dinarello, 2011).

\subsection{Erythrocytes}

The ability of some strains of A. actinomycetemcomitans to cause $\beta$-hemolysis on blood agar plates has been known for many years (Kimuzuka et al., 1996). Later, it was found that red blood cell lysis caused by $A$. actinomycetemcomitans involved an interaction with leukotoxin (Balashova et al., 2006). Different strains of the bacterium with various expressions of leukotoxin show a specific pattern when cultured on blood agar plates containing fresh horse blood. Red blood cells lack the receptor LFA-1, a key molecule for leukotoxin-induced leukocyte lysis (Lally et al., 1994). The cellular and molecular mechanisms for the hemolytic effect of leukotoxin are unknown. The lysis of erythrocytes by the leukotoxin has recently been reviewed (Kachlany 2010). It remains to be answered whether the hemolytic capacity of leukotoxin is an important virulence factor in periodontitis.

\section{Conclusions}

The ability of leukotoxin to cause death of all subsets of cells with hematopoetic origin might contribute to help the bacterium to survive the host immune response and also to release compounds essential for bacterial growth (Fig. 10). The more recent discoveries that leukotoxin mediates activation and release of proteolytic enzymes from PMNs and proinflammatory cytokines from monocytes/macrophages indicate a more direct role of leukotoxin in the disease pathogenesis. Unfortunately there is no animal model available for studying the virulence mechanisms of leukotoxin because of its specificity against defense cells of human or old world monkey origin. However, the strong correlation between presence of highly leukotoxic (JP2-clone) A. actinomycetemcomitans and development of attachment loss in adolescents indicates an important role of leukotoxin in the pathogenesis of aggressive periodontitis (Haubek, 2010). 


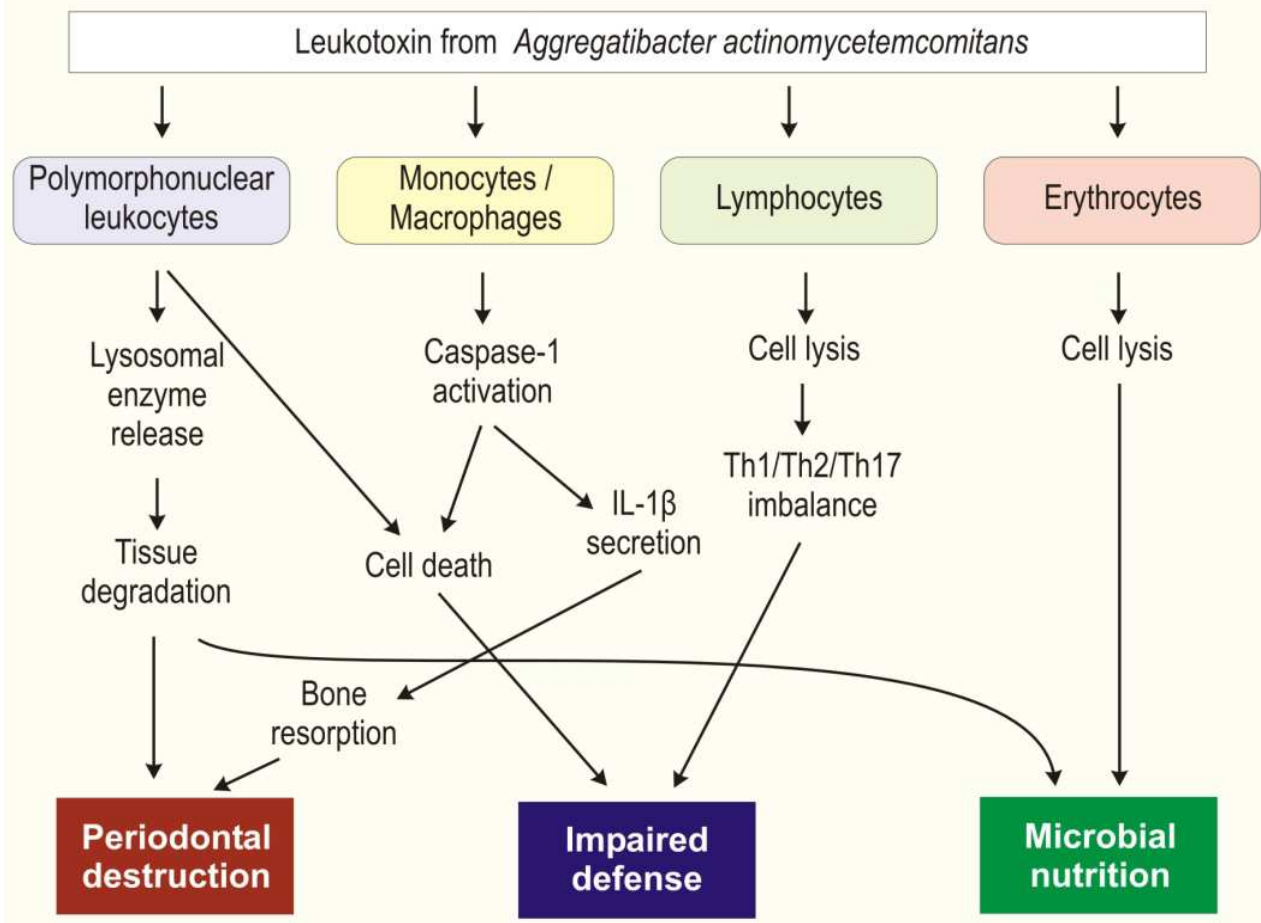

Fig. 10. Effects of importance for development of periodontal inflammation and local tissue destruction derived from the interactions of A. actinomycetemcomitans leukotoxin with human blood cells.

\section{Acknowledgment}

The text chapter was supported by research grants from the fund of Västerbotten County (TUA), Sweden.

\section{References}

Baehni, P., Tsai, C.C., McArthur, W.P., Hammond, B.F.\& Taichman, N.S. (1979). Interaction of inflammatory cells and oral microorganisms. VIII. Detection of leukotoxic activity of a plaque-derived gram-negative microorganism. Infection and Immunity, Vol. 24, No. 1, (Apr 1979), pp. 233-243, ISSN 1098-5522

Balashova, N.V., Crosby, J.A., Al Ghofaily, L. \& Kachlany, S.C. (2006). Leukotoxin confers beta-hemolytic activity to Actinobacillus actinomycetemcomitans. Infection and Immunity, Vol. 74, No. 4, (Apr 2006), pp 2015-2021, ISSN 1098-5522

Balashova, N.V., Park, D.H., Patel, J.K., Figurski, D.H. \& Kachlany, S.C. (2007). Interaction between leukotoxin and $\mathrm{Cu}, \mathrm{Zn}$ superoxide dismutase in Aggregatibacter 
actinomycetemcomitans. Infection and Immunity, Vol. 75, No. 9, (Sep 2007), pp. 44904497, ISSN 1098-5522

Balashova, N.V., Shah, C., Patel, J.K., Megalla, S. \& Kachlany SC. (2009). Aggregatibacter actinomycetemcomitans $\mathrm{LtxC}$ is required for leukotoxin activity and initial interaction between toxin and host cells. Gene, Vol. 443, No. 1-2, (Aug 2009), pp.42-47, ISSN 0378-1119

Belibasakis, G. N., Mattsson, A., Wang, Y., Chen, C. \& Johansson, A. (2004). Cell cycle arrest of human gingival fibroblasts and periodontal ligament cells by Actinobacillus actinomycetemcomitans: involvement of the cytolethal distending toxin. APMIS, Vol. 112, No. 10 (Oct 2004), pp.674-685, ISSN 1600-0463

Berezow, A.B.\& Darveau, R.P. (2011). Microbial shift and periodontitis. Periodontology 2000, Vol. 55, No. 5 (Feb 2011), pp.36-47. ISSN 1600-0757

Berthold, P., Forti, D., Kieba, I.R., Rosenbloom, J., Taichman, N.S., Lally, E.T. (1992). Electron immunocytochemical localization of Actinobacillus actinomycetemcomitans leukotoxin. Oral Microbiology and Immunology, Vol 7, No. 1, (Feb 1992), pp. 24-27, ISSN 2041-1014

Brage, M., Holmlund, A. \& Johansson, A. (2011). Humoral immune response to Aggregatibacter actinomycetemcomitans leukotoxin. Journal of Periodontal Research, Vol. 46, No. 2, (Apr 2011), pp.170-175, ISSN 1600-0765

Brogan, J. M., Lally, E. T., Poulsen, K., Kilian, M. \& Demuth, D. R. (1994). Regulation of Actinobacillus actinomycetemcomitans leukotoxin expression: Analysis of the promoter regions of leukotoxic and minimally leukotoxic strains. Infection and Immunity, Vol. 62, No.2, (Feb 1994), pp.501-508, ISSN 1098-5522

Califano, J.V., Pace, B.E., Gunsolley, J.C., Schenkein, H.,A, Lally, E.T. \& Tew, J.G. (1997). Antibody reactive with Actinobacillus actinomycetemcomitans leukotoxin in earlyonset periodontitis patients. Oral Microbiology and Immunology, Vol. 12, No. 1, (Feb 1997), pp.20-26, ISSN 2041-1014

Carlsson, G., Wahlin, Y.B., Johansson, A., Olsson, A., Eriksson. T., Claesson, R., Hänström, L. \& Henter, J.I. (2006). Periodontal disease in patients from the original Kostmann family with severe congenital neutropenia. Journal of Periodontology, Vol. 77, No. 4, (Apr 2006), pp.744-751, ISSN 1943-3670

Chen, C., Kittichotirat, W., Si, Y. \& Bumgarner. R. (2009). Genome sequence of Aggregatibacter actinomycetemcomitans serotype c strain D11S-1. Journal of Bacteriology, Vol. 191, No. 23, pp.7378-7379 (Oct 2009), ISSN 1098-5530

Claesson, R., Johansson, A., Belibasakis, G., Hänström, L. \& Kalfas, S. (2002). Release and activation of matrix metalloproteinase 8 from human neutrophils triggered by the leukotoxin of Actinobacillus actinomycetemcomitans. Journal of Periodontal Research, Vol. 37, No. 5, (Oct 2002), pp.353-359, ISSN 1600-0765

Claesson, R., Lagervall, M., Höglund-Aberg, C., Johansson, A. \& Haubek, D. (2011). Detection of the highly leucotoxic JP2 clone of Aggregatibacter actinomycetemcomitans in members of a Caucasian family living in Sweden. Journal of Clinical Periodontology, Vol. 38, No. 2, (Feb 2011), pp.115-121, ISSN 0303-6979

Crosby, J.A. \& Kachlany, S.C. (2007). TdeA, a TolC-like protein required for toxin and drug export in Aggregatibacter (Actinobacillus) actinomycetemcomitans. Gene, Vol. 388, No. 1-2, (Feb 2007), pp.83-92, ISSN 0378-1119 
Darveau, R.P. (2010). Periodontitis: a polymicrobial disruption of host homeostasis. Nature Review Microbiology, Vol. 8, No. 7, (Jul 2010), pp.481-490. ISSN 1740-1526

de Haar, SF., Hiemstra, P.S., van Steenbergen, M.T., Everts, V. \& Beertsen, W. (2006). Role of polymorphonuclear leukocyte-derived serine proteinases in defense against Actinobacillus actinomycetemcomitans. Infection and Immunity, Vol. 74, No. 9, (Sep 2006), pp.5284-5291, ISSN 1098-5522

Deas, D.E.\& Mealey, B.L. (2010). Response of chronic and aggressive periodontitis to treatment. Periodontology 2000, Vol. 53, No. 1, (Jun 2010), pp.154-166, ISSN 16000757

Deas, D.E., Mackey, S.A. \& McDonnell, H.T. (2003). Systemic disease and periodontitis: manifestations of neutrophil dysfunction. Periodontology 2000, Vol. 32, No. 1, (Jun 2003), pp.82-104, ISSN 1600-0757

Deasy, M..J, Vogel, R.I., Macedo-Sobrinho, B., Gertzman, G. \& Simon, B. (1980). Familial benign chronic neutropenia associated with periodontal disease. A case report. Journal of Periodontology, Vol. 5, No. 4, (April 1980), pp.206-210 ISSN 1943-3670

Defraia, E. \& Marinelli, A. (2001). Oral manifestations of congenital neutropenia or Kostmann syndrome. Journal of Clinical Pediatric Dentistry, Vol. 26, No. 1, (2001), pp 99-102, ISSN 1053-4628

De Vree, H., Steenackers, K. \& De Boever, J.A. (2000). Periodontal treatment of rapid progressive periodontitis in 2 siblings with Papillon-Lefèvre syndrome: 15-year follow-up. Journal of Clinical Periodontology, Vol. 27, No. 5, (May 200), pp.354-60, ISSN 0303-6979

Dileepan, T., Kachlany, S.C., Balashova, N.V., Patel. J., Maheswaran, S.K. (2007). Human CD18 is the functional receptor for Aggregatibacter actinomycetemcomitans leukotoxin. Infection and Immunity, Vol. 75, No. 10, (Oct 2007), pp.4851-4856, ISSN 1098-5522

Dinarello, C.A. (2009). Immunological and inflammatory functions of the interleukin-1 family. Annual Review of Immunology, Vol. 27, (Apr 2009), pp 519-550, ISSN 07320582

Dinarello, C.A. (2009). Interleukin-1beta and the autoinflammatory diseases. (2009). New England Journal of Medicine, Vol, 360, No. 23, (Jun 2009), pp.2467-2470, ISSN 15334406

Dinarello, C.A. (2010). Anti-inflammatory Agents: Present and Future. Cell, Vol. 140, No. 6, (Mar 2010), pp.935-950, ISSN 0092-8674

Dinarello, C.A. (2011). Interleukin-1 in the pathogenesis and treatment of inflammatory diseases. Blood. Vol. 117: No. 14, (Apr 2011), pp. 3720-3732, ISSN 1528-0020

Dustin, M.L., Bivona, T.G. \& Philips, M.R. (2004). Membranes as messengers in T cell adhesion signaling. Nature Immunology, Vol. 5, No. 4, pp.363-372, (Apr 2004), ISSN 1529-2908

Ebersole, J.L. (2003). Humoral immune responses in gingival crevice fluid: local and systemic implications. Periodontology 2000, Vol. 31, No. 1, (Feb 2003), pp.135-166, ISSN 1600-0757

Fine, D. H., Kaplan, J. B., Kachlany, S. C. \& Schreiner, H. C. (2006). How we got attached to Actinobacillus actinomycetemcomitans: a model for infectious diseases. Periodontology 2000, Vol. 42, No. 1 (Oct 2006), pp.114-157, ISSN 1600-0757 
Fine, D.H., Markowitz, K., Furgang, D., Fairlie, K., Ferrandiz, J., Nasri, C., McKiernan, M. \& Gunsolley J. (2007). Aggregatibacter actinomycetemcomitans and its relationship to initiation of localized aggressive periodontitis: longitudinal cohort study of initially healthy adolescents. Journal of Clinical Microbiology, Vol. 45, No. 12, (Dec 2007), pp.3859-3869, ISSN 1098-660X

Fong, K.P., Pacheco, C.M., Otis, L.L., Baranwal, S., Kieba, I.R., Harrison, G., Hersh, E.V., Boesze-Battaglia, K. \& Lally, E.T. (2006). Actinobacillus actinomycetemcomitans leukotoxin requires lipid microdomains for target cell cytotoxicity. Cellular Microbiology, Vol. 8, No. 11, (Nov 2006), pp 1753-1767, ISSN 1462-5822

Gallant, C.V., Sedic, M., Chicoine, E.A., Ruiz, T. \& Mintz, K.P. (2008). Membrane morphology and leukotoxin secretion are associated with a novel membrane protein of Aggregatibacter actinomycetemcomitans. Journal of Bacteriology, Vol. 190, No. 17, (Sep 2008), pp.5972-5980, ISSN 0021-9193

Garlet, G.P. (2010). Destructive and protective roles of cytokines in periodontitis: a reappraisal from host defense and tissue destruction viewpoints. Journal of Dental Research Vol. 89, No 12, (Aug 2010), pp.1349-1363, ISSN 1544-0591

Geissmann, F., Manz, M.G., Jung, S., Sieweke, M.H., Merad, M. \& Ley, K. (2010). Development of monocytes, macrophages, and dendritic cells. Science, Vol. 327, No. 5966, (Feb 2010), pp.656-661, ISSN 0036-8075

Haubek D., Poulsen, K., Kilian, M. (2007). Microevolution and patterns of dissemination of the JP2 clone of Aggregatibacter (Actinobacillus) actinomycetemcomitans. Infection and Immunity, 75, 3080-3088, ISSN 1098-5522

Haubek, D. (2010). The highly leukotoxic JP2 clone of Aggregatibacter actinomycetemcomitans: evolutionary aspects, epidemiology and etiological role in aggressive periodontitis. APMIS, Vol. 118, No. 130 Supplement, (Sep 2010), pp.153, ISSN 1600-0463

Haubek, D., Dirienzo, J.M., Tinoco, E.M., Westergaard, J., López, N.J., Chung, C.P., Poulsen, K. \& Kilian, M. (1997). Racial tropism of a highly toxic clone of Actinobacillus actinomycetemcomitans associated with juvenile periodontitis. Journal of Clinical Microbiology, Vol. 35, No. 12, (Dec 1997), pp.3037-3042, ISSN 1098-660X

Haubek, D., Ennibi, O-K., Poulsen, K., Vaeth, M., Poulsen, S. \& Kilian, M. (2008) Risk of aggressive periodontitis in adolescent carriers of the JP2 clone of Aggregatibacter (Actinobacillus) actinomycetemcomitans in Morocco: a perspective longitudinal cohort study. Lancet, Vol. 371, No. 9608, (Jan 2008), pp.237-242, ISSN 1474-547X

He, T., Nishihara, T., Demuth, D.R.\& Ishikawa, I. (1999). A novel insertion sequence increases the expression of leukotoxicity in Actinobacillus actinomycetemcomitans clinical isolates. Journal of Periodontology, Vol. 70, No. 11, (Nov 1999), pp.1261-1268, ISSN 1943-3670

Henderson, B., Ward, J.M. \& Ready, D. (2010). Aggregatibacter (Actinobacillus) actinomycetemcomitans: a triple A* periodontopathogen? Periodontology 2000, Vol. 54, No. 1, (Oct 2010), pp.78-105, ISSN 1600-0757

Johansson, A. (2011). Aggregatibacter actinomycetemcomitans Leukotoxin: A Powerful Tool with Capacity to Cause Imbalance in the Host Inflammatory Response. Toxins, Vol. 3, No. 3, (Mar 2011), pp.242-259, ISSN 2072-6651 
Johansson, A., Claesson, R., Belibasakis, G., Makoveichuk, E., Hänström, L., Olivecrona, G., Sandström, G. \& Kalfas, S. (2001). Protease inhibitors, the responsible components for the serum-dependent enhancement of Actinobacillus actinomycetemcomitans leukotoxicity. European Journal Oral Science, Vol. 109, No. 5, (Oct 2001), pp. 335-341, ISSN 1600-0722

Johansson, A., Claesson, R., Hänström, L. \& Kalfas, S. (2003), Serum-mediated release of leukotoxin from the cell surface of the periodontal pathogen Actinobacillus actinomycetemcomitans. European Journal Oral Science, Vol. 111, No. 3, (Jun 2003), pp. 209-215, ISSN 1600-0722

Johansson, A., Claesson, R., Hänström, L., Sandström, G. \& Kalfas, S. (2000b). Polymorphonuclear leukocyte degranulation induced by leukotoxin from Actinobacillus actinomycetemcomitans. Journal of Periodontal Research, Vol. 35, No. 2, (Apr 2000), pp.85-92, ISSN 1600-0765

Johansson, A., Eriksson, M., Åhrén, A-M., Boman, K., Jansson, J.H., Hallmans, G. \& Johansson, I. (2011). Prevalence of systemic immunoreactivity to Aggregatibacter actinomycetemcomitans leukotoxin in relation to the incidence of myocardial infarction. BMC Infectious Diseases, Vol. 11, No. 55, (Mar 2011), ISSN 1471-2334

Johansson, A., Hänström, L. \& Kalfas, S. (2000a). Inhibition of Actinobacillus actinomycetemcomitans leukotoxicity by bacteria from the subgingival flora. Oral Microbiology and Immunology, Vol. 15, No. 4 (Aug 2000), pp.218-225, ISSN 20411014

Johansson, A., Johansson, I., Eriksson., M., Ahrén, A.M., Hallmans, G. \& Stegmayr, B. (2005). Systemic antibodies to the leukotoxin of the oral pathogen Actinobacillus actinomycetemcomitans correlate negatively with stroke in women. Cerebrovascular Diseases Vol. 20, No, 4, (Aug 2005), pp.226-232, ISSN 1015-9770

Johansson, A., Sandström, G., Claesson, R., Hänström, L. \& Kalfas, S. (2000c). Anaerobic neutrophil-dependent killing of Actinobacillus actinomycetemcomitans in relation to the bacterial leukotoxicity. European Journal Oral Science, Vol. 108, No. 23, (Apr 2000), pp.136-146, ISSN 1600-0722

Kachlany, S.C. (2010). Aggregatibacter actinomycetemcomitans leukotoxin: from threat to therapy. Journal of Dental Research Vol. 89, No 6, (Mar 2010), pp.561-570, ISSN 15440591

Kachlany, S.C., Fine, D.H. \& Figurski, D.H. (2000). Secretion of RTX leukotoxin by Actinobacillus actinomycetemcomitans. Infection and Immunity, Vol. 68, No. 11, (Nov 2000), pp.6094-6100, ISSN 1098-5522

Kantarci, A. \& Van Dyke, T.E. (2005). Resolution of inflammation in periodontitis. Journal of Periodontology, Vol. 76, No. 11 Supplement, (Nov 2005), pp.2168-2174, ISSN 19433670

Kantarci, A.M., Oyaizu, K. \& Van Dyke, T.E. (2003). Neutrophil-mediated tissue injury in periodontal disease pathogenesis: findings from localized aggressive periodontitis. Journal of Periodontology, Vol. 74, No. 1, (Jan 2003), pp.66-75, ISSN 1943-3670

Kaplan, J.B., Schreiner, H.C., Furgang, D. \& Fine DH. (2002). Population structure and genetic diversity of Actinobacillus actinomycetemcomitans strains isolated from 
localized juvenile periodontitis patients. Journal of Clinical Microbiology, Vol. 40, No. 4, (Apr 2002), pp.1181-1187, ISSN 1098-660X

Kato, S., Kowashi. Y. \& Demuth, D.R. (2002), Outer membrane-like vesicles secreted by Actinobacillus actinomycetemcomitans are enriched in leukotoxin. Microbial Pathogenicity, Vol. 32, No. 1, (Jan 1992), pp.1-13, ISSN 0882-4010

Kelk, P., Abd, H., Claesson, R., Sandström, G., Sjöstedt, A, \& Johansson, A. (2011). Cellular and molecular response of human macrophages exposed to Aggregatibacter actinomycetemcomitans leukotoxin. Cell Death and Disease, Vol. 10, No. 2, (Mar 2011), pp. e126, ISSN 2041-4889

Kelk, P., Claesson, R., Chen, C., Sjostedt, A. \& Johansson, A. (2008). IL-1beta secretion induced by Aggregatibacter (Actinobacillus) actinomycetemcomitans is mainly caused by the leukotoxin. International Journal of Medical Microbiology, Vol. 298, No. 5-6, (Jul 2008), pp.529-541, ISSN 1438-4221

Kelk, P., Claesson, R., Hanstrom, L., Lerner, UH., Kalfas, S. \& Johansson, A. (2005). Abundant secretion of bioactive interleukin-1beta by human macrophages induced by Actinobacillus actinomycetemcomitans leukotoxin. Infection and Immunity, Vol. 73, No. 1, (Jan 2005), pp.453-458, ISSN 1098-5522

Kelk, P., Johansson, A., Claesson, R., Hanstrom, L. \& Kalfas, S. (2003). Caspase 1 involvement in human monocyte lysis induced by Actinobacillus actinomycetemcomitans leukotoxin. Infection and Immunity, Vol. 71, No. 8, (Aug 2003), pp.4448-4455, ISSN 1098-5522

Kieba, I.R., Fong, K.P., Tang, H.Y., Hoffman, K.E., Speicher, D.W., Klickstein, L.B. \& Lally, E..T. (2007). Aggregatibacter actinomycetemcomitans leukotoxin requires beta-sheets 1 and 2 of the human CD11a beta-propeller for cytotoxicity. Cellular Microbiology, Vol. 9, No. 11, (Nov 2007), pp. 2689-2699, ISSN 1462-5822

Kilian, M., Frandsen, E.V., Haubek, D. \& Poulsen K. (2006). The etiology of periodontal disease revisited by population genetic analysis. Periodontology 2000, Vol. 42 No. 1, (Oct 2006), pp.158-179, ISSN 1600-0757

Kimizuka, R., Miura, T. \& Okuda, K. (1996). Characterization of Actinobacillus actinomycetemcomitans hemolysin. Microbiology and Immunology, Vol. 40, No. 10, (1996), pp.717-723, ISSN 0022-1732

Kinane, D., Bouchard, P. and on behalf of group E of the European Workshop on Periodontology, Periodontal diseases and health. (2008): Consensus Report of the Sixth European Workshop on Periodontology. Journal of Clinical Periodontolology, Vol. 35, No. 8 Supplement, (Sep 2008), pp 333-337, ISSN 0303-6979

Kinane, D.F. \& Lappin, D.F. (2002). Immune processes in periodontal disease: a review. Annals of Periodontology, Vol. 7, No. 1, (Dec 2002), pp.62-71, ISSN 1553-0841

Kittichotirat, W., Bumgarner, R.E., Asikainen, S. \& Chen C. (2011). Identification of the Pangenome and Its Components in 14 Distinct Aggregatibacter actinomycetemcomitans Strains by Comparative Genomic Analysis. PLos One, Vol. 6, No. 7, (Jul 2011), pp.e22420, ISSN 1932-6203

Kleinfelder, J.W., Topoll, H.H., Preus, H.R., Müller, R.F., Lange, D.E. \& Böcker, W. (1998). Microbiological and immunohistological findings in a patient with PapillonLefèvre syndrome. Journal of Clinical Periodontolology, Vol. 23, No. 1l, (Nov 1998), pp.1032-1038, ISSN 0303-6979 
Korostoff, J., Wang,, J.F., Kieba, I., Miller, M., Shenker, B.J. \& Lally, E.T. (1998). Actinobacillus actinomycetemcomitans leukotoxin induces apoptosis in HL-60 cells. Infection and Immunity, Vol. 66, No. 9, (Sep 1998), pp.4474-4483, ISSN 1098-5522

Kraig, E., Dailey, T. \& Kolodrubetz, D. (1990) Nucleotide sequence of the leukotoxin gene from Actinobacillus actinomycetemcomitans: homology to the alphahemolysin/leukotoxin gene family. Infection and Immunity, Vol. 58, No. 4, (Apr 1990), pp. 920-929, ISSN 1098-5522

Kuhnert, P. \& Christensen, H. (2008). Eds. Pasteurellaceac biology, genomics and molecular aspects. Norfolk, UK: Caister Academic Press (Aug 2008), pp.1-267, ISSN 1466-531X

Källestål, C., Matsson, L. \& Persson, S. (1991). Proximal attachment loss in Swedish adolescents. Journal of Clinical Periodontology, Vol. 18, No. 10, (Nov 1991), pp.760765, ISSN 0303-6979

Lally, E.T., Golub, E.E. \& Kieba, I.R. (1994). Identification and immunological characterization of the domain of Actinobacillus actinomycetemcomitans leukotoxin that determines its specificity for human target cells. Journal of Biological Chemistry, Vol. 269, No. 49, (Dec 1994), pp. 31289-31295, ISSN 0021-9258

Lally, E.T., Golub, E.E., Kieba, I.R., Taichman, N.S., Rosenbloom, J., Rosenbloom, J.C., Gibson, C.W. \& Demuth, D.R. (1989), Analysis of the Actinobacillus actinomycetemcomitans leukotoxin gene. Delineation of unique features and comparison to homologous toxins. Journal of Biological Chemistry, Vol. 264, No. 26, (Sep 1989), pp. 15451-15456, ISSN 0021-9258

Lally, E.T., Hill, R.B,, Kieba. I.R. \& Korostoff, J. (1999). The interaction between RTX toxins and target cells. Trends in Microbiology, Vol. 7, No. 9, (Sep 1999), pp. 356-361, ISSN 1369-5274

Lally, E.T., Kieba, I.R., Sato, A., Green, C.L., Rosenbloom, J., Korostoff, J., Wang, J.F., Shenker, B.J., Ortlepp, S., Robinson, M.K.\& Billings, P.C. (1997). RTX toxins recognize a beta2 integrin on the surface of human target cells. Journal of Biological Chemistry, Vol. 272, No. 48, (Nov 1997), pp.30463-30469, ISSN 0021-9258

Lally, E.T., Kieba, I.R, Golub, E.E., Lear, J.D. \& Tanaka, J.C. (1996). Structur/function Aspects of Actinobacillus actinomycetemcomitans leukotoxin. Journal of Periodontology, Vol. 67, (1996), pp 298-308, ISSN 1943-3670

Lamster, I.B. \& Novak, M.J. (1992), Host mediators in gingival crevicular fluid: implications for the pathogenesis of periodontal disease. Critical Review in Oral Biology and Medicine, Vol. 3, No. 1-2, (1992), pp.31-60, ISSN 1544-1113

Latz, E. (2010). The inflammasomes: mechanisms of activation and function. Current Opinion in Immunology, Vol, 22, No. 1, (Feb 2010), pp.28-33, ISSN 0952-7915

Lear, J.D., Karakelian, D., Furblur, U., Lally, E.T. \& Tanaka, J.C. (2000). Conformational studies of Actinobacillus actinomycetemcomitans leukotoxin: partial denaturation enhances toxicity. Biochimica et Biophysica Acta, Vol. 1476, No. 2, (Feb 2000), pp. 350362, ISSN 0006-3002

Linhartová, I., Bumba, L., Mašín, J., Basler, M., Osička, R., Kamanová, J., Procházková, K., Adkins, I., Hejnová-Holubová, J., Sadílková, L., Morová, J. \& Šebo, P. (2010). RTX proteins: a highly diverse family secreted by a common mechanism. FEMS Microbiology Reviews, Vol. 34, No. 6, (Apr 2010), pp 1076-1112, ISSN 1574-6976 
Mangan, D.F., Taichman, N.S., Lally, E.T. \& Wahl, S.M. (1991). Lethal effects of Actinobacillus actinomycetemcomitans leukotoxin on human T lymphocytes. Infection and Immunity, Vol. 59, No. 9, (Sep 1991), pp.3267-3272, ISSN 1098-5522

McArthur, W.P., Tsai, C.C., Baehni, P.C., Genco, R.J. \& Taichman, N.S. (1981). Leukotoxic effects of Actinobacillus actinomycetemcomitans. Modulation by serum components. Journal of Periodontal Research, Vol. 16, No. 2, (Mar 1981), pp.159-170, ISSN 16000765

Miao, E.A., Leaf, I.A., Treuting, P.M., Mao, D.P., Dors, M., Sarkar, A., Warren, S.E., Wewers, M.D. \& Aderem, A. (2010). Caspase-1-induced pyroptosis is an innate immune effector mechanism against intracellular bacteria. Nature Immunology, Vol. 11, No. 12, (Dec 2010), pp.1136-1142, ISSN 1529-2908

Nørskov-Lauritsen, N. \& Kilian, M. (2006). Reclassification of Actinobacillus actinomycetemcomitans, Haemophilus aphrophilus, Haemophilus paraphrophilus and Haemophilus segnis as Aggregatibacter actinomycetemcomitans gen. nov., comb. nov., Aggregatibacter aphrophilus comb. nov. and Aggregatibacter segnis comb. nov., and emended description of Aggregatibacter aphrophilus to include V factor-dependent and $\mathrm{V}$ factor-independent isolates. International Journal of Systemic Evolutionary Microbiology, Vol. 56, No. 9, (Sep 2006), pp.2135-2146, ISSN 1466-5034

Nishihara, T. \& Koseki, T. (2004). Microbial etiology of periodontitis. Periodontology 2000, Vol. 36, No. 1, (Oct 2004), pp.14-26, ISSN 1600-0757

Ohlrich, E., Cullinan, M. \& Seymour, G. (2009). The immunopathogenesis of periodontal disease. Australian Dental Journal, Vol 54, No. 1 Supplement, (Sep 2009),pp 2-10, ISSN 1834-7819

Ohta, H., Kato, K., Kokeguchi, S., Hara, H., Fukui, K. \& Murayama. Y. (1991). Nucleasesensitive binding of an Actinobacillus actinomycetemcomitans leukotoxin to the bacterial cell surface. Infection and Immunity, Vol. 59, No. 12, (Dec 1991), pp.145994605, ISSN 1098-5522

Ohta. H., Hara, H., Fukui, K., Kurihara, H., Murayama, Y. \& Kato, K. (1993). Association of Actinobacillus actinomycetemcomitans leukotoxin with nucleic acids on the bacterial cell surface. Infection and Immunity, Vol. 61, No. 11, (Nov 1993), pp.4878-4884, ISSN 1098-5522

Okada M, Kobayashi T, Ito S, Yokoyama T, Komatsu Y, Abe A, Murasawa A, Yoshie H. (2011). Antibody Responses to Periodontopathic Bacteria in Relation to Rheumatoid Arthritis in Japanese Adults. Journa of Periodontology, Vol. 82, No. 10: (Oct 2011), pp 1433-1441, ISSN ISSN 1943-3670

Paino, A., Tuominen, H., Jääskeläinen, M., Alanko, J., Nuutila, J., Asikainen, S.E., Pelliniemi, L.J., Pöllänen, M.T., Chen, C. \& Ihalin R. (1979). Trimeric form of intracellular ATP synthase subunit $\beta$ of Aggregatibacter actinomycetemcomitans binds human interleukin-1ß. PLos One, Vol. 6, No. 4, (Apr 2011), pp.e18929, ISSN 1932-6203

Pihlstrom, B.C., Michalowicz, B.S. \& Johnson, D.W. (2005). Periodontal diseases. Lancet, Vol. 366, No. 9499, (Nov 2005), pp.1809-1820, ISSN 1474-547X

Preshaw, P.M. \& Taylor, J.J. (2011). How has research into cytokine interactions and their role in driving immune responses impacted our understanding of periodontitis? 
Journal of Clinical Periodontology, Vol. 38 No. 11 Supplement (Mar 2011), pp.60-84, ISSN 0303-6979

Pütsep, K., Carlsson, G., Boman, H.G. \& Andersson, M. (2002). Deficiency of antibacterial peptides in patients with morbus Kostmann: an observation study. Lancet, Vol. 360, No. 9340, (Oct 2002), pp.1144-1149, ISSN 1474-547X

Rabie, G., Lally, E.T. \& Shenker, B.J. (1988). Immunosuppressive properties of Actinobacillus actinomycetemcomitans leukotoxin. Infection and Immunity, Vol. 56, No. 5, (May 1988), pp.122-127, ISSN 1098-5522

Reichart, P.A \& Dornow, H. (1978). Gingivo-periodontal manifestations in chronic benign neutropenia. Journal of Clinical Periodontology, Vol. 5 No. 1, (Feb 1978), pp.346-361, ISSN 0303-6979

Reinhardt, R.A., Stoner, J.A., Golub, L.M., Lee, H.M., Nummikoski, P.V., Sorsa T. \& Payne, J.B. (2010). Association of gingival crevicular fluid biomarkers during periodontal maintenance with subsequent progressive periodontitis. Journal of Periodontology, Vol. 81, No. 2 Supplement, (Feb 2010), pp.251-259, ISSN 1943-3670

Rivas, F. (2010). In this Issue: Inflammation. Cell, Vol. 140, No. 6, (Mar 2010), pp.755-757, ISSN 0092-8674

Rylev, M. \& Kilian, M. (2008). Prevalence and distribution of principal periodontal pathogens worldwide. Journal of Clinical Periodontology, Vol. 35 No. 8 Supplement (Sep 2008), pp.346-361, ISSN 0303-6979

Sağlam, F., Atamer, T., Onan, U., Soydinç, M. \& Kiraç, K. (1995). Infantile genetic agranulocytosis (Kostmann type). A case report.. Journal of Periodontology, Vol. 66, No. 9, (Sep 1998), pp.808-810, ISSN 1943-3670

Sato, N., Takahashi, K., Ohta, H., Kurihara, H., Fukui, K., Murayama, Y.\& Taniguchi, S. (1993). Effect of $\mathrm{Ca}^{2+}$ on the binding of Actinobacillus actinomycetemcomitans leukotoxin and the cytotoxicity to promyelocytic leukemia HL-60 cells. Biochemistry and Molecular Biology International, Vol. 29, No. 5, (Apr 1993), pp.899-905, ISSN 10399712

Schett, G. (2011). Effects of inflammatory and anti-inflammatory cytokines on the bone. European Journal of Clinical Investigation. Early view (May 2011), pp 1365-2362, ISSN

Shenker, B.J., Vitale, L.A., Keiba, I., Harrison, G., Berthold, P., Golub, E. \& Lally, E.T. (1994). Flow cytometric analysis of the cytotoxic effects of Actinobacillus actinomycetemcomitans leukotoxin on human natural killer cells. Journal of Leukocyte Biology, Vol. 55, No. 2, (Feb 1994), pp.153-160, ISSN 1938-3673

Shimaoka, M., Xiao, T., Liu, J.H., Yang, Y., Dong, Y., Jun, C.D., McCormack, A., Zhang, R., Joachimiak, A., Takagi, J., Wang, J.H. \& Springer T.A. (2003). Structures of the alpha L I domain and its complex with ICAM-1 reveal a shape-shifting pathway for integrin regulation. Cell, Vol. 112, No. 1, (Jan 2003), pp.99-111, ISSN 0092-8674

Simpson, D.L., Berthold, P. \& Taichman, N.S. (1988). Killing of human myelomonocytic leukemia and lymphocytic cell lines by Actinobacillus actinomycetemcomitans leukotoxin. Infection and Immunity, Vol. 56, No. 5, (May 1988), pp.1162-1166, ISSN 1098-5522

Sjödin, B., Arnrup, K., Matsson, L., Wranne, L., Carlsson, J. \& Hänström, L. (1995). Periodontal and systemic findings in children with marginal bone loss in the 
primary dentition. Journal of Clinical Periodontology, Vol. 22, No. 3, (Mar 1995), pp.214-224, ISSN 0303-6979

Socransky, S.S. \& Haffajee, A.D. (2005). Periodontal microbial ecology. Periodontology 2000, Vol. 38, No. 1, (Jun 2005), pp.135-187, ISSN 1600-0757

Stabholz A, Taichman NS, Soskolne WA. (1996). Occurrence of Actinobacillus actinomycetemcomitans and anti-leukotoxin antibodies in some members of an extended family affected by Papillon-Lefèvre syndrome. Journal of Periodontology, Vol. 66, No. 7, (Jul 1995), pp.653-657, ISSN 1943-3670

Stanley, P., Koronakis, V. \& Hughes. C. (1991). Mutational analysis supports a role for multiple structural features in the C-terminal secretion signal of Escherichia coli haemolysin. Molecular Microbiology, Vol. 5, No. 10, (Oct 1991), pp.2391-2403, ISSN 1365-2958

Stanley, P., Packman, L.C., Koronakis, V. \& Hughes, C. (1994). Fatty acylation of two internal lysine residues required for the toxic activity of Escherichia coli hemolysin. Science, Vol. 266, No. 5193, (Dec 1994), pp.1992-1996, ISSN 0036-8075

Taichman, N.S., Dean, R.T. \& Sanderson, C.J. (1980). Biochemical and morphological characterization of the killing of human monocytes by a leukotoxin derived from Actinobacillus actinomycetemcomitans. Infection and Immunity, Vol. 28, No. 1, (Apr 1980), pp.258-268, ISSN 1098-5522

Takada, K., Saito, M-, Tsuzukibashi, O., Kawashima, Y., Ishida, S, \& Hirasawa, M. (2010). Characterization of a new serotype $g$ isolate of Aggregatibacter actinomycetemcomitans. Oral Molecular Microbiology, Vol. 25, No. 3 (Jun 2010), pp.200-206, ISSN 2041-1014

Taubman, M.A., Valverde, P., Han, X. \& Kawai, T. (2005). Immune response: the key to bone resorption in periodontal disease. Journal of Periodontology, Vol. 76, No. 11 Supplement, (Nov 2005), pp.2033-2041, ISSN 1943-3670

Tempel, T.R., Kimball, H.R., Kakenashi, S, \& Amen, C.R. (1972). Host factors in periodontal disease: periodontal manifestations of Chediak-Higashi Syndrome. Journal of Periodontal Research, Vol. 10, (1972), pp.26-27, ISSN 1600-0765

Teng, Y.T. (2003). The role of acquired immunity and periodontal disease progression. Critical Review in Oral Biology and Medicine, Vol. 14, No. 4, (Jul 2003), pp.237-252, ISSN 1544-1113

Tsai, C.C., McArthur, W.P., Baehni, P.C., Hammond, B.F. \& Taichman, N.S. (2011). Extraction and partial characterization of a leukotoxin from a plaque-derived Gram-negative microorganism. Infection and Immunity, Vol. 25, No. 1, (Jul 1979), pp.427-439, ISSN 1098-5522

Van der Velden U, Abbas F, Armand S, Loos BG, Timmerman MF, Van der Weijden GA, Van Winkelhoff AJ, Winkel EG. (2006). Java project on periodontal diseases. The natural development of periodontitis: risk factors, risk predictors and risk determinants. Journal of Clinical Periodontology, Vol. 33, No. 8, (Aug 2006), pp.540548, ISSN 0303-6979

Velazco, C.H., Coelho. C., Salazar. F., Contreras. A., Slots, J. \& Pacheco, J.J. (1999) Microbiological features of Papillon-Lefèvre syndrome periodontitis. Journal of Clinical Periodontology, Vol. 26, No. 9, (Sep 1999), pp.622-627, ISSN 0303-6979 
Welch, R.A. (2001). RTX toxin structure and function: a story of numerous anomalies and few analogies in toxin biology. Current Topic in Microbiological Immunology, Vol. 257, (2001), pp 85-111, ISSN 0070-217X

Zambon, J.J., Slots, J. \& Genco, R.J. (1983). Serology of oral Actinobacillus actinomycetemcomitans and serotype distribution in human periodontal disease. Infection and Immunity, Vol. 41, No 1, (Jul 1983), pp.19-27, ISSN 1098-5522 


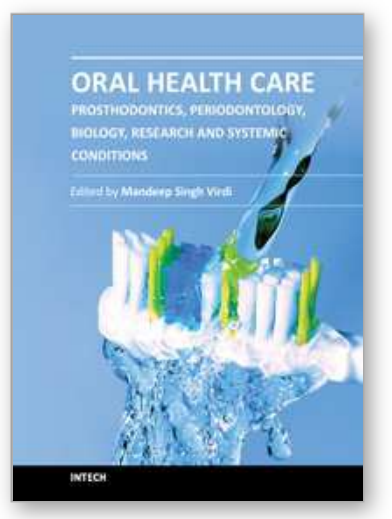

\author{
Oral Health Care - Prosthodontics, Periodontology, Biology, \\ Research and Systemic Conditions \\ Edited by Prof. Mandeep Virdi
}

ISBN 978-953-51-0040-9

Hard cover, 372 pages

Publisher InTech

Published online 29, February, 2012

Published in print edition February, 2012

Geriatric dentistry, or gerodontics, is the branch of dental care dealing with older adults involving the diagnosis, prevention, and treatment of problems associated with normal aging and age-related diseases as part of an interdisciplinary team with other healthcare professionals. Prosthodontics is the dental specialty pertaining to the diagnosis, treatment planning, rehabilitation, and maintenance of the oral function, comfort, appearance, and health of patients with clinical conditions associated with missing or deficient teeth and/or oral and maxillofacial tissues using biocompatible materials. Periodontology, or Periodontics, is the specialty of oral healthcare that concerns supporting structures of teeth, diseases, and conditions that affect them. The supporting tissues are known as the periodontium, which includes the gingiva (gums), alveolar bone, cementum, and the periodontal ligament. Oral biology deals with the microbiota and their interaction within the oral region. Research in oral health and systemic conditions concerns the effect of various systemic conditions on the oral cavity and conversely helps to diagnose various systemic conditions.

\title{
How to reference
}

In order to correctly reference this scholarly work, feel free to copy and paste the following:

Anders Johansson and Sotos Kalfas (2012). Virulence Mechanisms of Leukotoxin from Aggregatibacter actinomycetemcomitans, Oral Health Care - Prosthodontics, Periodontology, Biology, Research and Systemic Conditions, Prof. Mandeep Virdi (Ed.), ISBN: 978-953-51-0040-9, InTech, Available from:

http://www.intechopen.com/books/oral-health-care-prosthodontics-periodontology-biology-research-andsystemic-conditions/virulence-mechanisms-of-leukotoxin-from-aggregatibacter-actinomycetemcomitans

\section{INTECH}

open science | open minds

\section{InTech Europe}

University Campus STeP Ri

Slavka Krautzeka 83/A

51000 Rijeka, Croatia

Phone: +385 (51) 770447

Fax: +385 (51) 686166

www.intechopen.com

\section{InTech China}

Unit 405, Office Block, Hotel Equatorial Shanghai

No.65, Yan An Road (West), Shanghai, 200040, China 中国上海市延安西路65号上海国际贵都大饭店办公楼 405 单元

Phone: +86-21-62489820

Fax: +86-21-62489821 
(C) 2012 The Author(s). Licensee IntechOpen. This is an open access article distributed under the terms of the Creative Commons Attribution 3.0 License, which permits unrestricted use, distribution, and reproduction in any medium, provided the original work is properly cited. 